Check for updates

Cite this: RSC Adv., 2020, 10, 35906

Received 3rd September 2020

Accepted 22nd September 2020

DOI: 10.1039/dOra07997a

rsc.li/rsc-advances

\title{
Synthesis of chiral 1,4-oxazepane-5-carboxylic acids from polymer-supported homoserine $\uparrow$
}

\author{
Petra Králová, ${ }^{a}$ Barbora Lemrová, ${ }^{b}$ Michal Maloň (D) ${ }^{c}$ and Miroslav Soural (D) *ac
}

The preparation of novel 1,4-oxazepane-5-carboxylic acids bearing two stereocenters is reported in this article. Fmoc-HSe(TBDMS)-OH immobilized on Wang resin was reacted with different nitrobenzenesulfonyl chlorides and alkylated with 2-bromoacetophenones to yield $N$-phenacyl nitrobenzenesulfonamides. Their cleavage from the polymer support using trifluoroacetic acid (TFA) led to the removal of the silyl protective group followed by spontaneous lactonization. In contrast, TFA/ triethylsilane $\left(\mathrm{Et}_{3} \mathrm{SiH}\right)$-mediated cleavage yielded 1,4-oxazepane derivatives as a mixture of inseparable diastereomers. The regioselectivity/stereoselectivity depended on the substitution of the starting 2bromoacetophenones and was studied in detail. Catalytic hydrogenation of the nitro group improved the separability of the resulting diastereomeric anilines, which allowed us to isolate and fully characterize the major isomers.

\section{Introduction}

Chiral seven-membered heterocycles bearing one or more heteroatoms in their skeleton are an interesting group of compounds with unique physico-chemical and biological properties. The prominent heterocyclic scaffold within this group is represented by 1,4-oxazepanes, which occur in both synthetic compounds and natural products (Fig. 1). ${ }^{1-6}$

Compounds bearing 1,4-oxazepane scaffolds have been reported as potent anticonvulsants ${ }^{7}$ and antifungal agents ${ }^{5,8}$ or agents to treat inflammatory bowel disease, ${ }^{9}$ lupus nephritis ${ }^{10}$ and respiratory diseases, including asthma and bronchiectasis. ${ }^{11,12}$ Over the past decade, synthetic chemists have struggled to develop different strategies to access 1,4-oxazepanes from various starting materials.

The most robust synthetic approaches reported to date are based on intramolecular cyclization of alkenols, ${ }^{13,14}$ alkynols ${ }^{15,16}$ or hydroxyketones ${ }^{16}$ typically using Brönsted or Lewis acids; however, some alternative methods of limited applicability have also been described recently. ${ }^{17-25}$

Although the synthetic availability of chiral 1,4-oxazepanes has already been determined, the decoration of the scaffold with reactive functional groups amenable to further diversification remains a challenging task due to the limited

${ }^{a}$ Department of Organic Chemistry, Faculty of Science, Palacký University, 77146 Olomouc, Czech Republic. E-mail: miroslav.soural@upol.cz

${ }^{b} J E O L$ (U.K.) Ltd., JEOL House, Silver Court, Watchmead, Welwyn Garden City, Hertfordshire $A L 71 L T, U K$

'Institute of Molecular and Translational Medicine, Faculty of Medicine and Dentistry, Palacký University, Hněvotínská 5, 779 o0 Olomouc, Czech Republic

$\dagger$ Electronic supplementary information (ESI) available. See DOI: 10.1039/d0ra07997a applicability of previously developed procedures for functionalizing starting materials. In our previous contribution, we reported the simple synthesis of chiral morpholines starting from resin-bound serine. ${ }^{26}$ Using either TFA- or TFA/Et ${ }_{3} \mathrm{SiH}$-induced cleavage of the corresponding polymer-supported intermediates (Fig. 2), we synthesized either dihydrooxazine-3-carboxylic acids or morpholine-3-carboxylic acids with full control of the newly formed stereocenter. Later, we extended this method to the simple synthesis of fused $[6+7]^{27,28}$ or $[6+6]^{29,30}$ morpholines. To eventually synthesize the corresponding homological compounds, we decided to use polymer-supported homoserine to access the 1,4-oxazepane-5-carboxylic acids suitable for further modification. In this article, we report on the applicability, regioselectivity and stereoselectivity of the proposed method.

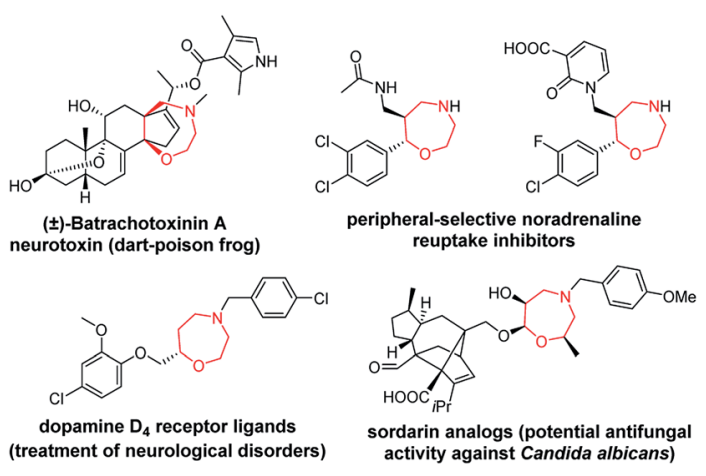

Fig. 1 Selected pharmacologically relevant compounds bearing a 1,4oxazepane scaffold. ${ }^{1-6}$ 


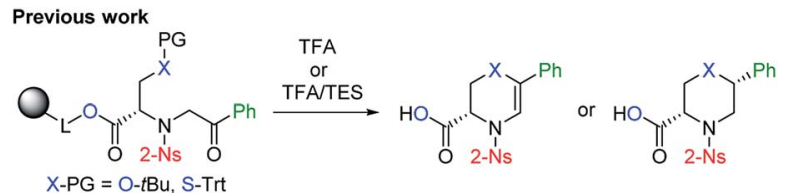
$X-P G=0-t B u, S-T r t$

This work

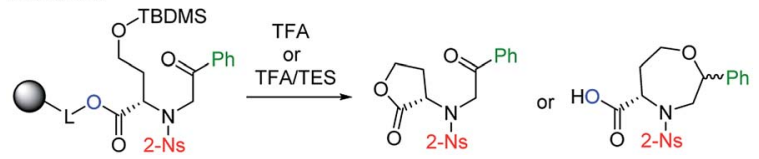

Fig. 2 Previously reported stereoselective synthesis of chiral (thio) morpholines and the application of the method to homological starting material.

\section{Results and discussion}

Fmoc-HSe(TBDMS)-OH was prepared from homoserine in two steps $^{31,32}$ and immobilized on Wang resin using the 1-hydroxybenzotriazole ( $\mathrm{HOBt}$ )/diisopropylcarbodiimide (DIC) technique to suppress racemization. The key intermediate $\mathbf{3 a}$ was synthesized according to our previous protocols ${ }^{26}$ consisting of Fmoc-protective group cleavage, reaction with 2-nitrobenzenesulfonyl chloride (2-Ns-Cl) and alkylation using 2-bromoacetophenone (Scheme 1). Inspired by the smooth cyclization of serine-based analogs to 3,4-dihydro-1,4-oxazine-3carboxylic acids ${ }^{26}$ we hypothesized that exposure of resin $3 a$ to TFA could yield the corresponding homologous product, i.e., 4,5,6,7-tetrahydro-1,4-oxazepine-5-carboxylic acid 4a. The reaction yielded a single product with $87 \%$ crude purity (calculated from HPLC-UV traces at $205-400 \mathrm{~nm}$ ) and $74 \%$ overall yield (calculated from the ${ }^{1} \mathrm{H}$ NMR spectrum of the purified product). Although HRMS analysis corresponded to the molecular mass

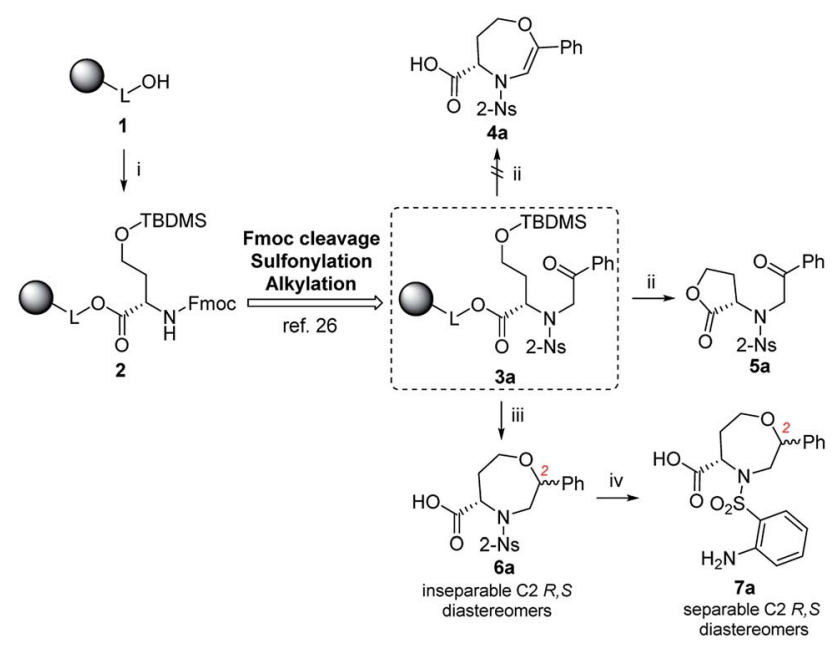

Scheme 1 The reactivity of resin-bound intermediate $3 a$ under different reaction conditions. Reagents and conditions: (i) 1-hydroxybenzotriazole (HOBt), 4-(dimethylamino)pyridine (DMAP), diisopropylcarbodiimide (DIC), N,N-dimethylformamide (DMF), $\mathrm{CH}_{2} \mathrm{Cl}_{2}, 24 \mathrm{~h}$, rt; (ii) $50 \%$ trifluoroacetic acid (TFA) $/ \mathrm{CH}_{2} \mathrm{Cl}_{2}, 1 \mathrm{~h}$, rt; (iii) TFA/triethylsilane $\left(\mathrm{Et}_{3} \mathrm{SiH}\right) / \mathrm{CH}_{2} \mathrm{Cl}_{2}$ (10:1: 9), 30 min, rt; (iv) $\mathrm{H}_{2}, 10 \%$ palladium on carbon ( $\mathrm{Pd} / \mathrm{C}$ ) or platinum(Iv) oxide ( $\mathrm{PtO}_{2}$ ), 2-isopropanol (IPA), $24 \mathrm{~h}, \mathrm{rt}$. of suggested product 4a, NMR analysis (see ESI for details $\dagger$ ) revealed preferential lactonization, which yielded compound 5a. Interestingly, when $\mathrm{Et}_{3} \mathrm{SiH}$ was added to the cleavage cocktail, a different course of reaction was observed. We received two chromatographically inseparable compounds with identical molecular masses (as indicated by HPLC-UV-MS analysis, the combined crude purity was $85 \%$ ). To eventually improve the separability, we performed catalytic hydrogenation using palladium on carbon $(\mathrm{Pd} / \mathrm{C})$ in 2 -isopropanol (IPA), ${ }^{28}$ which again afforded a mixture of two isomers (the combined crude purity was $91 \%$, and the ratio was $56: 44$, as calculated from HPLC-UV traces at $205-400 \mathrm{~nm}$ ); however, in this case, reversephase chromatography (RP-HPLC) indicated possible separation. Consequently, the major isomer was successfully isolated using semipreparative RP-HPLC at $34 \%$ overall yield (calculated from the ${ }^{1} \mathrm{H}$ NMR spectrum of the purified product) and subjected to detailed NMR investigation.

We recorded and analyzed ${ }^{1} \mathrm{H},{ }^{13} \mathrm{C}\left\{{ }^{1} \mathrm{H}\right\}$, APT, ${ }^{1} \mathrm{H}^{-1} \mathrm{H}$ COSY, ${ }^{1} \mathrm{H}_{-}{ }^{1} \mathrm{H}$ NOESY, ${ }^{1} \mathrm{H}^{-13} \mathrm{C}$ HMQC, ${ }^{1} \mathrm{H}_{-}{ }^{13} \mathrm{C}$ HMBC and ${ }^{1} \mathrm{H}^{-15} \mathrm{~N}$ HMBC NMR data to determine the constitution. Complete assignment of the ${ }^{1} \mathrm{H},{ }^{13} \mathrm{C}$ and ${ }^{15} \mathrm{~N}$ signals was possible and is shown in the ESI (Fig. S17-S19 and Table S2 $\uparrow$ ). In brief, by means of the homonuclear and heteronuclear correlation data, we identified the 1,4-oxazepane-5-carboxylic acid, phenyl and 2aminobenzenesulfonyl moieties indicating the structure of 7 a. The connectivity between the oxazepane and phenyl rings was confirmed by three long-range ${ }^{1} \mathrm{H}^{1}{ }^{13} \mathrm{C}$ correlations (see ESI, Fig. S18†). Finally, the planar structure was established by the ${ }^{1} \mathrm{H}^{-}{ }^{1} \mathrm{H}$ NOESY spectrum, which gave the key correlations between oxazepane protons and aminobenzenesulfonyl proton $\mathrm{H}^{19}$ and correlations between oxazepane protons and phenyl protons $\mathrm{H}^{9,13}$ (Fig. 3 and S19†). All the 1D and 2D NMR spectra can be found in the ESI (Fig. S20-S27†).

To determine the conformation and relative configuration of $7 \mathbf{a}$, we analyzed the ${ }^{1} \mathrm{H}-{ }^{1} \mathrm{H}$ coupling constants on the oxazepane ring and the NOE correlations in detail. Despite the spatial flexibility of seven membered rings leading to multiple possible conformational states, the analysis of vicinal ${ }^{1} \mathrm{H}^{-1} \mathrm{H}$ couplings indicated that the scaffold existed in the most energetically favourable chair conformation (Fig. 3). Since the configuration of the $\mathrm{C} 5$ stereocenter was defined by the configuration of the starting material $(S)$, the configuration of the newly formed C2 stereocenter was assigned as $R$.

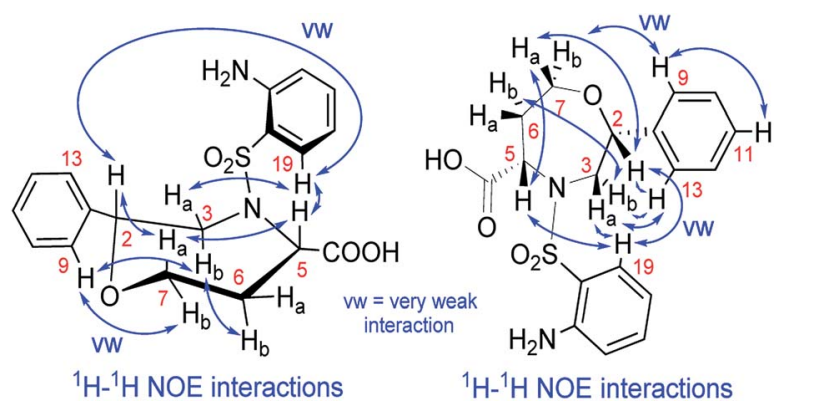

Fig. 3 The NOE correlations prove the constitution and configuration of oxazepane derivative $7 a$. 
Table 1 Comparison of ${ }^{1} \mathrm{H}$ chemical shifts, splitting patterns, and ${ }^{2} \mathrm{~J}$ and ${ }^{3} \mathrm{~J}$ homonuclear couplings for derivatives $7 \mathrm{~b}^{2 R}$ and $7 \mathrm{~b}^{2 S}$

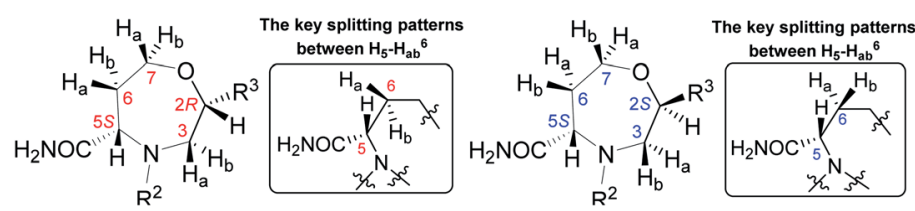

\begin{tabular}{|c|c|c|c|c|c|c|}
\hline \multirow[b]{2}{*}{ Position } & \multicolumn{3}{|l|}{ C2 $R$ isomer } & \multicolumn{3}{|l|}{ C2 $S$ isomer } \\
\hline & ${ }^{1} \mathrm{H}$ NMR $\delta_{\mathrm{H}}[\mathrm{ppm}]$ & $\begin{array}{l}\text { Splitting } \\
\text { pattern }\end{array}$ & $J[\mathrm{~Hz}]$ & ${ }^{1} \mathrm{H}$ NMR $\delta_{\mathrm{H}}[\mathrm{ppm}]$ & $\begin{array}{l}\text { Splitting } \\
\text { pattern }\end{array}$ & $J[\mathrm{~Hz}]$ \\
\hline $\mathrm{H}^{2}$ & 4.28 & dd & $9.3,1.2$ & 4.64 & dd & $8.7,1.6$ \\
\hline $\mathrm{H}_{\mathrm{a}}{ }^{3}$ & 3.82 & ddd & $16.2,1.2,1.2$ & 3.63 & dd & $14.2,1.6$ \\
\hline $\mathrm{H}_{\mathrm{b}}{ }^{3}$ & 3.53 & dd & $16.2,9.6$ & 3.43 & dd & $14.2,8.7$ \\
\hline $\mathrm{H}_{\mathrm{b}}{ }^{6}$ & 2.21 & dddd & $15.7,10.8,9.3,1.5$ & 2.10 & dddd & $15.8,11.0,4.5,3.0$ \\
\hline $\mathrm{H}_{\mathrm{a}}{ }^{7}$ & 3.67 & ddd & $12.9,9.3,1.0$ & 3.78 & ddd & $12.8,11.0,1.6$ \\
\hline $\mathrm{H}_{\mathrm{b}}{ }^{7}$ & 4.05 & ddd & $12.9,6.3,1.5$ & 4.02 & ddd & $12.8,4.5,3.0$ \\
\hline
\end{tabular}

Although we did not isolate and analyze the minor isomer of 7a, in the case of $\mathbf{7 b}$, RP-HPLC purification enabled the separation and isolation of both isomers. Thorough NMR structural analysis indicated the formation of $\mathrm{C} 2 R, S$ diastereomers $7 \mathbf{b}^{2 R}$ and $7 \mathbf{b}^{2 S}$ (Table 1 ). The ${ }^{1} \mathrm{H}$ NMR spectrum of $7 \mathbf{b}^{2 \boldsymbol{R}}$ was fairly similar to the spectrum of $7 \mathbf{a}$; hence, we concluded that this compound had the same configuration as $7 \mathbf{a}$. Compound $7 \mathbf{b}^{2 S}$ was analyzed by $1 \mathrm{D}$ and 2D NMR spectroscopy (see ESI, Fig. S34-S41 and Table S3†) to verify the planar structure, assign all the ${ }^{1} \mathrm{H}$ and ${ }^{13} \mathrm{C}$ signals and determine the relative configuration. Finally, we confirmed the configuration of $7 \mathbf{b}^{2 S}$ by analyzing the vicinal ${ }^{1} \mathrm{H}-{ }^{1} \mathrm{H}$ couplings on the oxazepane ring and NOE correlations (Fig. 4).

Table 1 summarizes the ${ }^{1} \mathrm{H}$ chemical shifts, splitting patterns, and ${ }^{2} J$ and ${ }^{3} J$ homonuclear couplings observed in $7 \mathbf{b}^{\mathbf{2 R}}$ and $7 \mathbf{b}^{2 S}$. While the chemical shifts differ rather insignificantly between the two diastereomers, the splitting pattern of signal $\mathrm{H}^{5}$ and ${ }^{3} J\left(\mathrm{H}^{5}-\mathrm{H}_{\mathrm{a}}{ }^{6}\right)$ and ${ }^{3} J\left(\mathrm{H}^{5}-\mathrm{H}_{\mathrm{b}}{ }^{6}\right)$ can be used to differentiate between $7 \mathbf{b}^{2 R}$ and $7 \mathbf{b}^{2 S}$. In the $\mathrm{C} 2 R$ isomer $7 \mathbf{b}^{2 R}$, two relatively large couplings and one very small long-range coupling leading to a doublet of doublet of doublets are observed. However, in

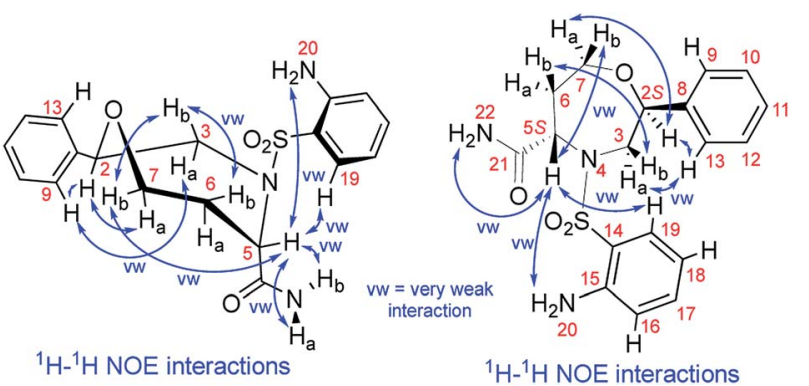

Fig. 4 The NOE correlations proving the configuration of oxazepane derivative $7 b^{2 S}$ the case of the C2 $S$ isomer $7 \mathbf{b}^{2 S}$, the vicinal coupling constants are smaller and equal or nearly equal, and hence, the signal takes the shape of a pseudotriplet (dd). The same trend was observed in all derivatives 6-7.

After proving the structure and formation of the two diastereomers, we tried to improve the stereoselectivity by using a lower reaction temperature $\left(0{ }^{\circ} \mathrm{C}\right.$ or $\left.-20{ }^{\circ} \mathrm{C}\right)$; however, a nearly equal ratio of isomers was obtained. Furthermore, we tested the use of $\mathrm{TMSOTf} / \mathrm{Et}_{3} \mathrm{SiH}$ as reported earlier for an analogical starting material, ${ }^{\mathbf{1 7}}$ but a complex mixture of unknown compounds was obtained.

To explain the different reaction outcomes depending on the composition of the cleavage cocktail, we suggested a reaction mechanism (Scheme 2). The protonation of intermediate 3a cleaved from the resin can be followed by intramolecular attack of ketone or carboxylic acid with the hydroxy group as the internal nucleophile. With respect to the higher electrophilicity of the ketone, we presume that the formation of intermediate $\mathbf{B}$ over $\mathbf{E}$ is preferred. Intermediate $\mathbf{B}$ can be further stabilized by the formation of intermediates $\mathbf{C}$ and $\mathbf{D}$; however, due to their limited stability, all the reactions in pathway A-D are reversible, which can lead to regeneration of starting material $\mathbf{A}$. The same is true for the formation of $\mathbf{E}$ from $\mathbf{A}$. In contrast, the conversion of $\mathbf{E}$ to $\mathbf{5 a}$ is irreversible, as lactone does not undergo hydrolysis under the conditions used. In the presence of $\mathrm{Et}_{3} \mathrm{SiH}$, the preferential formation of $\mathbf{B}$ is considered again; however, the subsequently formed intermediates $\mathbf{C}$ and $\mathbf{D}$ are attacked by triethylsilane as the external nucleophile, which leads to the formation of stable compound $\mathbf{6 a}$. Consequently, the formation of lactone 5a was not observed in this case.

After the determination of the reaction outcome, we used different starting materials to evaluate the limitations and scope of the methodology and to reveal the structure-regioselectivity and structure-stereoselectivity relationships. For this purpose, Wang resin was replaced with Rink amide resin, 
<smiles>CCCCOCC[C@H](C(=O)OCC(C)C)N([14CH3])CC(=O)c1ccccc1</smiles>

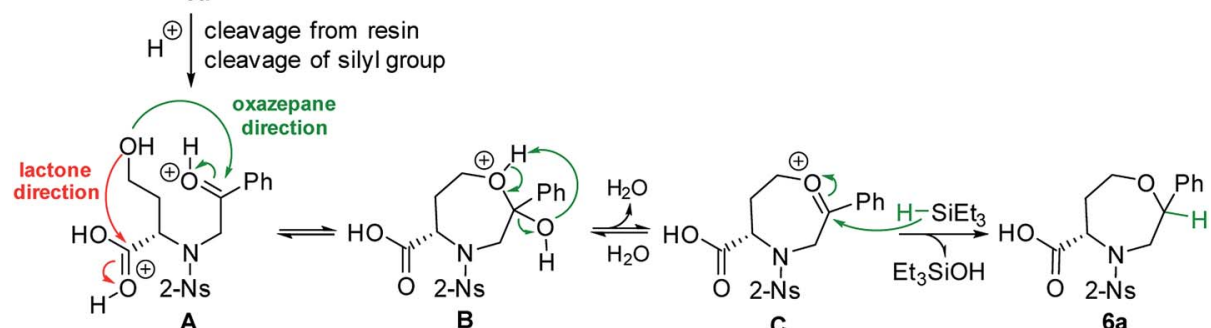

C $6 a$

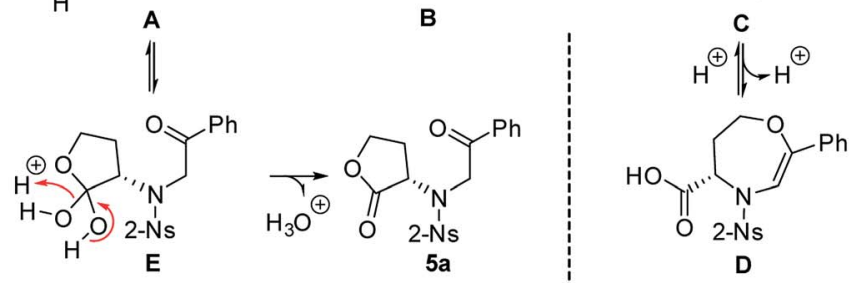

Scheme 2 The hypothetical mechanism explaining the different reactivity of intermediate $3 a$.

Wang-piperazine resin and BAL resin with immobilized propylamine ${ }^{26}$ to alter the carboxylic group to carboxamides. Furthermore, variously substituted sulfonyl chlorides and fourteen 2-bromoacetophenones bearing electron-donating or electron-withdrawing groups were selected, including one heterocyclic derivative (thienyl) and another aliphatic derivative (Me; Fig. 5).
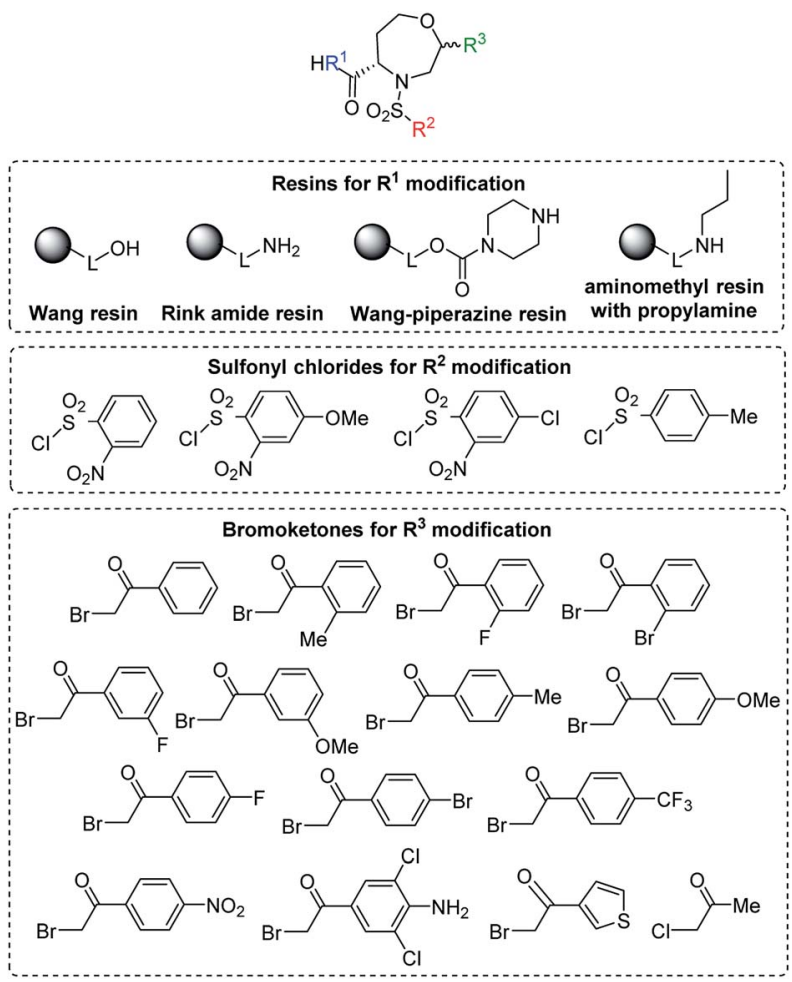

Fig. 5 General structure of target compounds and the list of the tested starting synthons (see Table 2 for the list of target compounds).
First, we tested the combination of 2-Ns-Cl and 2-bromoacetophenone with different resins. The use of Rink amide resin $\left(\mathrm{R}^{1}=\mathrm{NH}_{2}\right)$ required repetition of the alkylation step and yielded the final aniline $7 \mathbf{b}$ in $89 \%$ crude purity as a mixture of $\mathrm{C} 2 R, S$ diastereomers in a ratio of $45: 55$. Its RP-HPLC enabled the separation of both isomers in 9\% (C2 $R$ isomer) and $4 \%$ overall yields (C2 $S$ isomer, Table 2). In the case of the Wang-piperazine resin $\left(\mathrm{R}^{1}=\right.$ piperazin-1-yl), the $\mathrm{TFA} / \mathrm{Et}_{3} \mathrm{SiH}$-mediated cleavage of the corresponding sulfonamide from the resin unexpectedly caused the cleavage of the piperazine moiety, and oxazepane-5carboxylic acid derivative 7a was obtained as a mixture of $\mathrm{C} 2 R, S$ isomers in a ratio of $72: 28$. The major diastereomer was isolated in $10 \%$ overall yield. The use of BAL resin-immobilized propylamine failed in the alkylation step stage, which is in accordance with our previous results. ${ }^{26}$

After that, various sulfonylating agents (Fig. 5) were tested, starting from intermediate 2 and using 2-bromoacetophenone as the alkylating agent. In the case of sulfonamides $\mathbf{3 e}$ and $\mathbf{3 g}$ bearing 4-methoxy-2-nitrobenzenesulfonyl group or tosyl group as $\mathrm{R}^{2}$, the alkylation required a longer reaction time (2 and 6 days, respectively) to completion. The $\mathrm{TFA} / \mathrm{Et}_{3} \mathrm{SiH}$ cleavage of tosyl intermediate $3 \mathrm{~g}$ yielded the desired oxazepane in $73 \%$ crude purity as a partially separable mixture of $\mathrm{C} 2 R, S$ isomers in a ratio of $62: 38$. Its RP-HPLC purification yielded the major isomer $\mathrm{C} 2 R$ in $18 \%$ overall yield. In the case of $3 \mathbf{e}$ and $\mathbf{3 f}$ bearing 4-methoxy and 4-chloro-2-nitrobenzene-sulfonyl as $\mathrm{R}^{2}$ substituents, the nitro-oxazepane derivatives $\mathbf{6 e}$ and $\mathbf{6 f}$ were obtained as inseparable mixtures of $\mathrm{C} 2 R, S$ diastereoisomers in $81-90 \%$ crude purities. Similar to previously reported results, ${ }^{28}$ the hydrogenation of $\mathbf{6} \mathbf{f}$ led to undesired hydrogenolysis of the $\mathrm{C}-\mathrm{Cl}$ bond (Scheme 3). For this reason, $\mathrm{Pd} / \mathrm{C}$ was replaced with $\mathrm{PtO}_{2}$, which yielded aniline $7 \mathbf{f}$ in $86 \%$ crude purity as a mixture of $\mathrm{C} 2$ $R, S$ diastereomers in a ratio of $70: 30$. In this case, the isolation of the major isomer from the diastereomeric mixture was 
Table 2 The list of synthesized and fully characterized compounds ${ }^{a, b, c, d, e f}$
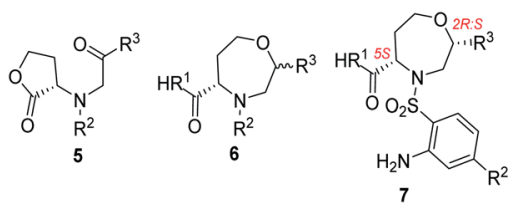<smiles>[R]C1=CN([C@H]2CCOC2=O)S(=O)(=O)c2ccc([R])cc2N1</smiles><smiles>[Y]CCN([Tl])C1CCOC1=O</smiles>

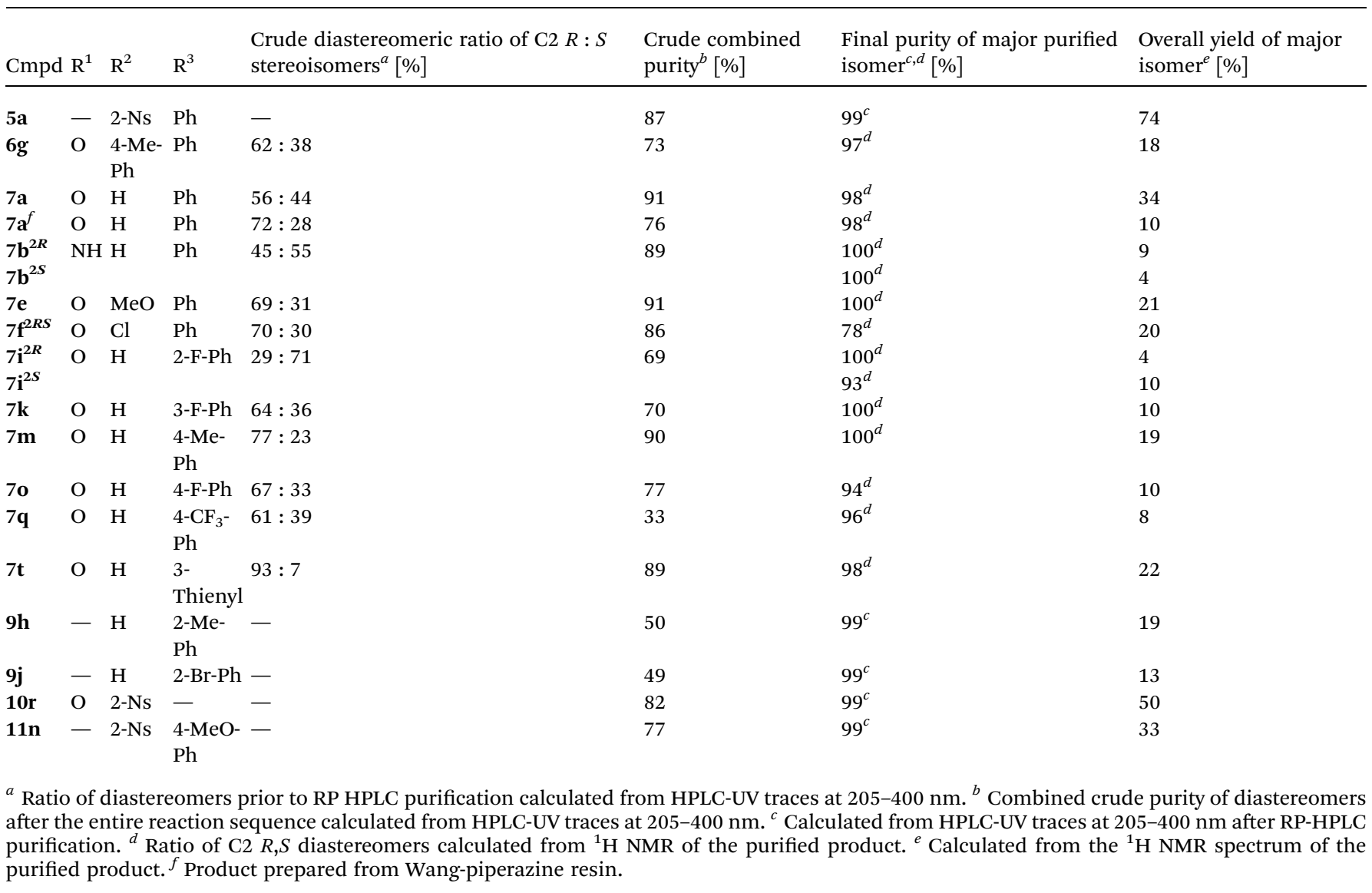

problematic and furnished the product C2 $R$ in only $78 \%$ diastereomeric purity. In the case of $6 \mathrm{e}$ bearing a 4-methoxy group, hydrogenation using $\mathrm{PtO}_{2}$ suppressed the previously reported demethylation, ${ }^{28}$ and the final compound $7 \mathrm{e}$ was obtained in $91 \%$ crude purity as a mixture of $\mathrm{C} 2 R, S$ diastereomers in a ratio of $69: 31$. RP-HPLC purification enabled the separation of the major C2 $R$ isomer in $21 \%$ overall yield.

Finally, we tested various 2-haloketones bearing electrondonating and electron-withdrawing groups in the $o^{-}, m^{-}$and $p$ -

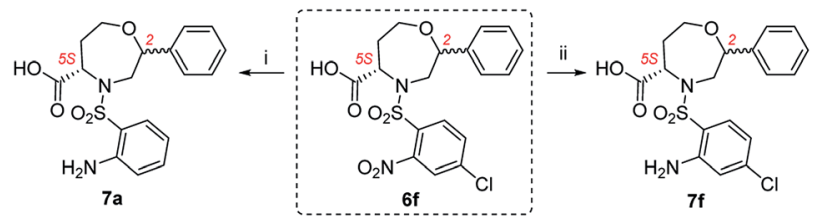

Scheme 3 Dehalogenation of oxazepane derivative $6 f$ during hydrogenation. Reagents and conditions: (i) $\mathrm{H}_{2}, \mathrm{Pd} / \mathrm{C}$, IPA, $24 \mathrm{~h}$, rt; (ii) $\mathrm{H}_{2}$, $\mathrm{PtO}_{2}$, IPA, $24 \mathrm{~h}$, rt. positions, and one heterocyclic and aliphatic derivative was included. All these building blocks were tested in combination with intermediate $\mathbf{2}$ and $2-\mathrm{Ns}-\mathrm{Cl}$. In the case of $7 \mathbf{j}$ and $7 \mathbf{p}$ bearing 2-Br-Ph or 4-Br-Ph as $\mathrm{R}^{3}, \mathrm{PtO}_{2}$ had to be used to avoid undesired debromination. The preferential formation of oxazepane was

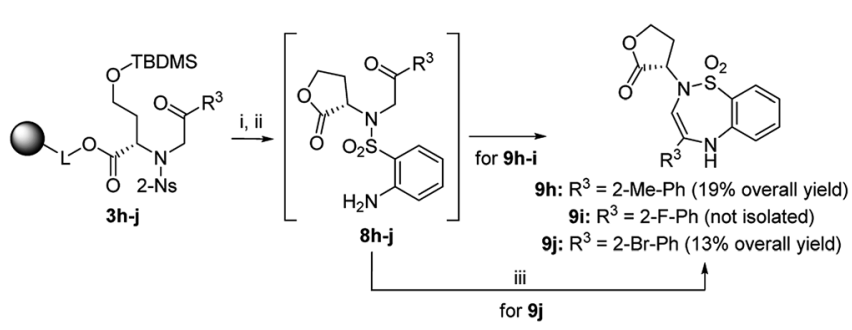

Scheme 4 Preferential lactonization and formation of benzothiadiazepine 1,1-dioxide 9. Reagents and conditions: (i) TFA/Et $3 \mathrm{SiH} / \mathrm{CH}_{2} \mathrm{Cl}_{2}$ (10 : 1 : 9), 30 min, rt; (ii) $\mathrm{H}_{2}, 10 \% \mathrm{Pd} / \mathrm{C}$ (for derivatives $9 \mathrm{~h}-\mathrm{i}$ ) or $\mathrm{PtO}_{2}$ (for derivative 9j), IPA, $24 \mathrm{~h}$, rt; (iii) $5 \% \mathrm{TFA} / \mathrm{CH}_{2} \mathrm{Cl}_{2}, 24 \mathrm{~h}$, rt. 


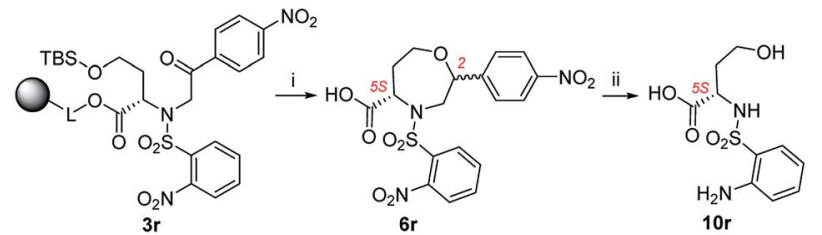

Scheme 5 Cleavage of oxazepane derivative $6 r$ during hydrogenation. Reagents and conditions: (i) $\mathrm{TFA} / \mathrm{Et}_{3} \mathrm{SiH} / \mathrm{CH}_{2} \mathrm{Cl}_{2}$ (10:1:9), $30 \mathrm{~min}, \mathrm{rt}$; (ii) $\mathrm{H}_{2}, \mathrm{Pd} / \mathrm{C}, \mathrm{IPA}, 24 \mathrm{~h}$, rt.

observed in each case. In the case of $\mathbf{7 p}$, inseparable $\mathrm{C} 2 R, S$ diastereomers were isolated in $14 \%$ overall yield as diastereomeric anilines in a ratio of $42: 58$. In the case of $3 \mathbf{i}$ bearing 2-F$\mathrm{Ph}$ as $\mathrm{R}^{3}$, the regioselectivity was compromised, and the TFA/ $\mathrm{Et}_{3} \mathrm{SiH}$ reaction yielded 1,4-oxazepane $\mathbf{6 i}$ accompanied by lactone $5 \mathbf{i}$ ( $26 \%$ according to HPLC). The following hydrogenation of the reaction mixture yielded the corresponding diastereomeric aniline $7 \mathbf{i}$ (69\% combined crude purity) and aminolactone 8i, which spontaneously cyclized to benzothiadiazepine 1,1-dioxide $9 \mathbf{i}$ (26\% according to HPLC-UV-MS analysis) (Scheme 4). ${ }^{33}$ In this case, RP-HPLC purification enabled the separation of both diastereomers. Intermediates $3 \mathbf{h}\left(\mathrm{R}^{3}=2\right.$-Me$\mathrm{Ph})$ and $3 \mathbf{j}\left(\mathrm{R}^{3}=2-\mathrm{Br}-\mathrm{Ph}\right)$ yielded lactones $\mathbf{5 h}$ and $\mathbf{5} \mathbf{j}$ as the major products $(72 \%$ and $64 \%$ crude purities). Their hydrogenation yielded the corresponding anilines $\mathbf{8 h}$ and $\mathbf{8 j}$, which were cyclized to benzothiadiazepine 1,1-dioxides $\mathbf{9 h}$ and $\mathbf{9 j}$. ${ }^{33}$ Derivatives $\mathbf{9 h}$ and $\mathbf{9 j}$ were isolated using semipreparative RP-HPLC at $19 \%$ overall yield and fully characterized. Interestingly, in contrast to previously reported results, ${ }^{33}$ compounds 9 were fully stable and did not undergo ring contraction to benzothiadiazine 1,1-dioxides.

In the case of $3 \mathbf{k}\left(3-\mathrm{F}-\mathrm{Ph}\right.$ as $\left.\mathrm{R}^{3}\right)$, the $\mathrm{TFA} / \mathrm{Et}_{3} \mathrm{SiH}$ reaction and the subsequent hydrogenation yielded diastereomeric aniline $7 \mathbf{k}$ in a ratio of $64: 36$ and $70 \%$ combined crude purity, and the major isomer was isolated and fully characterized. On the other hand, intermediate $3 \mathbf{l}\left(3-\mathrm{MeO}-\mathrm{Ph}\right.$ as $\mathrm{R}^{3}$ ) yielded a mixture of oxazepane derivative $\mathbf{6 l}$ and lactone $\mathbf{1 1 1}$ in a ratio of approximately $1: 1$, and for this reason, the products were not isolated (Scheme 6). Intermediates $\mathbf{3 m}, \mathbf{3 0 - q}, \mathbf{t}$ were synthesized from $p$ substituted 2-bromoacetophenones (4-Me- $\mathrm{Ph}, 4-\mathrm{F}-\mathrm{Ph}, 4-\mathrm{Br}-\mathrm{Ph}$ and $4-\mathrm{CF}_{3}-\mathrm{Ph}$ as $\mathrm{R}^{3}$ ) and 3-thienyl derivative yielded oxazepanes $7 \mathbf{m}, \mathbf{7 0}-\mathbf{q}, \mathbf{t}$ as separable $\mathrm{C} 2 R, S$ diastereomers in variable ratios (Table 2) with combined crude purities in a range of 33$91 \%$. In the case of oxazepane derivative $6 \mathbf{r}\left(4-\mathrm{NO}_{2}-\mathrm{Ph}\right.$ as $\left.\mathrm{R}^{3}\right)$,

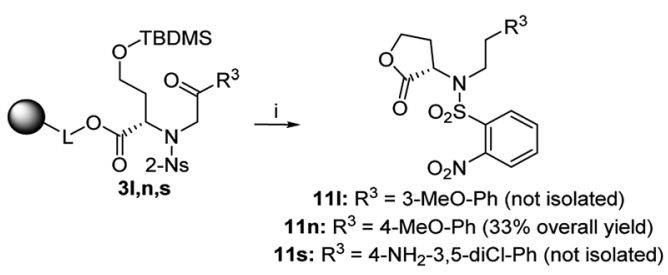

Scheme 6 Preferential lactonization followed by ketone reduction to products 11. Reagents and conditions: (i) $\mathrm{TFA} / \mathrm{Et}_{3} \mathrm{SiH} / \mathrm{CH}_{2} \mathrm{Cl}_{2}$ (10: $1: 9), 24 \mathrm{~h}, \mathrm{rt}$. hydrogenation using either $\mathrm{Pd} / \mathrm{C}$ or $\mathrm{PtO}_{2}$ led to cleavage of the heterocyclic scaffold, and compound 10r was isolated (Scheme 5 ) in $82 \%$ crude purity and $50 \%$ overall yield (Table 2 ).

In the cases of $3 \mathbf{n}\left(4-\mathrm{MeO}-\mathrm{Ph}\right.$ as $\left.\mathrm{R}^{3}\right)$ and $3 \mathbf{s}\left(4-\mathrm{NH}_{2}-3,5-\mathrm{diCl}-\mathrm{Ph}\right.$ as $\mathrm{R}^{3}$ ), we observed reversed regioselectivity, and after TFA/ $\mathrm{Et}_{3} \mathrm{SiH}$ cleavage, lactone derivatives 11n and 11s were formed exclusively; however, 11s was accompanied with oxazepane $\mathbf{6 s}$ as the minor product ( $30 \%$ crude purity). Due to the excess triethylsilane in the reaction mixture, the abovementioned derivatives were obtained as phenylethyl derivatives 11 (Scheme 6). The exposure to $\mathrm{TFA} / \mathrm{Et}_{3} \mathrm{SiH}$ had to be prolonged to make the reduction quantitative. In combination with the outcome obtained from intermediate $\mathbf{3 l}$ (3-MeO-Ph as $\mathrm{R}^{3}$ ), we can state that electron-donating $\mathrm{R}^{3}$ groups in the $m$ - or $p$-positions contribute to the formation of lactones, as they probably diminish the reactivity of adjacent ketones toward nucleophilic addition, which suppresses the formation of intermediate $\mathbf{C}$ (Scheme 2).

Similar to previously reported results, ${ }^{34}$ the alkylation step with 2-chloroacetone provided the corresponding oxazepane $\mathbf{6 u}$ in only $50 \%$ conversion. For this reason, the product was not isolated.

\section{Conclusions}

To conclude, we developed a simple methodology to prepare 2phenyl-substituted-1,4-oxazepane-5-carboxylic acid derivatives. Although the formation of the oxazepane scaffold was nonstereoselective, as in the case of serine-based analogs leading to chiral morpholines, ${ }^{26}$ the separation and full characterization of major diastereomers was feasible. The developed strategy provided rather minor limitations, e.g., competitive lactonization in the cases of $m$ - and $p$-electron-donating groups as $\mathrm{R}^{3}$ substituents. Importantly, the developed protocols and corresponding intermediates can be applied for the synthesis of differently fused 1,4-oxazepanes based on previously reported approaches targeted to fused morpholines. ${ }^{27-30}$

\section{Experimental section}

\section{General information}

Solvents and chemicals were purchased from Sigma-Aldrich (Milwaukee, WI, http://www.sigmaaldrich.com), Acros Organic (Geel, Belgium, http://www.acros.com) and Fluorochem (Hadfield, United Kingdom, http://www.fluorochem.co.uk). Wang resin (100-200 mesh, 1\% DVB, $\left.1.4 \mathrm{mmol} \mathrm{g}^{-1}\right)$, Rink resin (100200 mesh, 1\% DVB, $0.4 \mathrm{mmol} \mathrm{g}^{-1}$ ) and aminomethyl resin (100200 mesh, $1 \%$ DVB, $0.98 \mathrm{mmol} \mathrm{g}^{-1}$ ) were obtained from AAPPTec (Louisville, KY, http://www.aapptec.com). Solid-phase synthesis was carried out in plastic reaction vessels (syringes, each equipped with a porous disk) using a manually operated synthesizer (Torviq, Niles, MI, http://www.torviq.com). All reactions were carried out at ambient temperature $\left(23^{\circ} \mathrm{C}\right)$ unless stated otherwise. The synthesis of Fmoc-HSe(TBDMS)$\mathrm{OH},{ }^{31,32}$ immobilization of Fmoc-HSe(TBDMS)-OH on the resin ${ }^{26}$

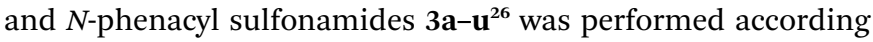
to these reported protocols. The LC-MS analyses were carried out on UHPLC-MS system consisting of UHPLC chromatograph 
Acquity with photodiode array detector and single quadrupole mass spectrometer (Waters), using X-Select C18 column with the mobile phase consisting of $10 \mathrm{mM}$ ammonium acetate (AmAc) in $\mathrm{H}_{2} \mathrm{O}$ and $\mathrm{MeCN}$. The ESI source operated at discharge current of $5 \mu \mathrm{A}$, vaporizer temperature of $350{ }^{\circ} \mathrm{C}$ and capillary temperature of $200^{\circ} \mathrm{C}$. For the LC/MS analysis, a sample of resin ( $\sim 5 \mathrm{mg}$ ) was treated with TFA in $\mathrm{CH}_{2} \mathrm{Cl}_{2}$, the cleavage cocktail was evaporated under a stream of nitrogen, and cleaved compounds extracted into $\mathrm{MeCN} / \mathrm{H}_{2} \mathrm{O}(20 \%$ or $50 \% ; 1 \mathrm{~mL})$. Purification was carried out on C18 semipreparative RP-HPLC with the gradient of $10 \mathrm{mM}$ aqueous AmAc and MeCN, flow rate $15 \mathrm{~mL} \mathrm{~min}^{-1}$ or by normal phase by silica gel chromatography. Residual solvents $\left(\mathrm{H}_{2} \mathrm{O}\right.$ and AmAc buffer) were lyophilized by the ScanVac Coolsafe $110-4$ working at $-110{ }^{\circ} \mathrm{C}$. All $1 \mathrm{D}$ and 2D NMR experiments were performed with using ECX500 spectrometer (JEOL RESONANCE, Tokyo, Japan) at magnetic field strength of $11.75 \mathrm{~T}$ corresponding to ${ }^{1} \mathrm{H}$ and ${ }^{13} \mathrm{C}$ resonance frequencies of 500.16 MHz and 125.77 MHz at $27^{\circ} \mathrm{C}$. Chemical shifts $(\delta)$ are reported in parts per million (ppm) and coupling constants $(J)$ are reported in Hertz $(\mathrm{Hz})$. The signals of MeCN- $d_{3}$ were set at $1.94 \mathrm{ppm}$ in ${ }^{1} \mathrm{H}$ NMR spectra and at $118.26 \mathrm{ppm}$ in ${ }^{13} \mathrm{C}$ NMR spectra. ${ }^{15} \mathrm{~N}$ chemical shifts were referenced to external $90 \%$ formamide in DMSO- $d_{6}$ at $112.00 \mathrm{ppm} .^{35}$ The assignment of ${ }^{1} \mathrm{H},{ }^{13} \mathrm{C}\left\{{ }^{1} \mathrm{H}\right\}$ and ${ }^{15} \mathrm{~N}$ signals was done by APT, ${ }^{1} \mathrm{H}-{ }^{1} \mathrm{H}$ COSY, ${ }^{1} \mathrm{H}-{ }^{1} \mathrm{H}$ NOESY, ${ }^{1} \mathrm{H}-{ }^{13} \mathrm{C}$ HMQC,${ }^{1} \mathrm{H}-{ }^{13} \mathrm{C} \mathrm{HMBC}$ and ${ }^{1} \mathrm{H}-{ }^{15} \mathrm{~N}$ HMBC. Abbreviations in NMR spectra: br. $\mathrm{s}-$ broad singlet, br. d - broad doublet, s - singlet, d - doublet, dd doublet of doublets, ddd - doublet of doublets of doublets, dddd - doublet of doublets of doublets of doublets, m multiplet. Acetate salt (residual agent from the semipreparative HPLC purification) exhibited a singlet at 2.09-2.53 ppm in ${ }^{1} \mathrm{H}$ NMR spectra and two resonances at $41.00 \mathrm{ppm}$ and $171.00 \mathrm{ppm}$ in ${ }^{13} \mathrm{C}$ NMR spectra. HRMS analysis was performed using LC-MS (Dionex Ultimate 3000, Thermo Fischer Scientific, MA, USA) with Exactive Plus Orbitrap high-resolution mass spectrometer (Thermo Exactive Plus, Thermo Fischer Scientific, MA, USA) operating at positive or negative full scan mode (120000 FWMH) in the range of 100-1000 m/z with electrospray ionization working at $150{ }^{\circ} \mathrm{C}$ and the source voltage of $3.6 \mathrm{kV}$. Chromatographic separation was performed on column Phenomenex Gemini (C18, $50 \times 2 \mathrm{~mm}, 3 \mu \mathrm{m}$ particle) with isocratic elution and mobile phase (MP) containing $\mathrm{MeCN} /$ $10 \mathrm{mM}$ AmAc $(80: 20 ; \mathrm{v} / \mathrm{v})$. The samples were dissolved in the initial MP. The acquired data were internally calibrated with phthalate as a contaminant in $\mathrm{MeOH}(\mathrm{m} / \mathrm{z}$ 297.15909). IR spectra were measured by DRIFT (Diffuse Reflectance Infrared Fourier Transform) on a Thermo Nicolet AVATAR 370 FTIR spectrometer. Absorbance peaks (wavenumbers) are reported in reciprocal centimeters $\left(\mathrm{cm}^{-1}\right)$ and transmittances $(T)$ are reported in percentages (\%). Specific optical rotations were measured on Automatic Compact Polarimeter POL-1/2 (ATAGO, Japan) with LED Light Source and $589 \mathrm{~nm}$ interference filter at $24{ }^{\circ} \mathrm{C}$. The length of cuvette was $2 \mathrm{~cm}$ and specific optical rotations are reported as follows: $[\alpha]_{\mathrm{D}}^{\mathrm{T}}$, concentration $\left(\mathrm{g} \mathrm{mL} \mathrm{mL}^{-1}\right)$ and solvent.

General method for calculation of yields using ${ }^{1} \mathrm{H}$ NMR. ${ }^{1} \mathrm{H}$ NMR spectra of external standard at three different concentration levels were measured. In each spectrum, the solvent signal was integrated followed by the integration of selected $\mathrm{H}^{\mathrm{Ar}}$ signal of external standard. Ratios of solvent/ standard signal areas along with known quantity of standard were used to construct a calibration curve. Then, ${ }^{1} \mathrm{H}$ NMR spectra of studied sample were measured and the ratio of solvent/sample (selected $\mathrm{H}^{\mathrm{Ar}}$ signal) areas was determined. Using the calibration curve, the quantity of compound in the sample was calculated.

General procedure for cleavage the TBDMS protecting group and lactonization $\mathbf{5 a - u}$. The polymer-supported intermediate $3 \mathbf{a}-\mathbf{u}(500 \mathrm{mg})$ was cleaved in the mixture of TFA/ $\mathrm{CH}_{2} \mathrm{Cl}_{2}(5 \mathrm{~mL}$, $50 \%$ ) for $1 \mathrm{~h}$ at room temperature. Then the resin was washed three times with fresh cleavage cocktail $(5 \mathrm{~mL})$ and the combined fractions were evaporated using a stream of nitrogen, lyophilized overnight and purified by semipreparative RP HPLC.

$(-)-(S)-2-N i t r o-N$-(2-oxo-2-phenethyl)- $N$-(2-

oxotetrahydrofuran-3-yl)benzenesulfonamide 5 a. Cleaved from $742 \mathrm{mg}$ of resin $3 \mathrm{a}\left(0.528 \mathrm{mmol} \mathrm{g}^{-1}, 0.342 \mathrm{mmol}\right.$ of substrate). White amorphous solid (117.4 mg, $0.291 \mathrm{mmol}, 74 \%)$. HPLC purity $99 \% .{ }^{1} \mathrm{H}$ NMR $\left(500 \mathrm{MHz}, \mathrm{MeCN}-d_{3}\right): \delta=8.26(\mathrm{dd}, J=7.7$, $1.6 \mathrm{~Hz}, 1 \mathrm{H}, \mathrm{HC} 9), 7.94-7.96$ (m, 2H, $\left.\mathrm{HC}^{18,22}\right), 7.74-7.83(\mathrm{~m}, 3 \mathrm{H}$, $\left.\mathrm{HC}^{10-12}\right), 7.63-7.67\left(\mathrm{~m}, 1 \mathrm{H}, \mathrm{HC}^{20}\right), 7.50-7.54\left(\mathrm{~m}, 2 \mathrm{H}, \mathrm{HC}^{19,21}\right)$, $5.25\left(\mathrm{~d}, J=19.2 \mathrm{~Hz}, 1 \mathrm{H}, \mathrm{H}_{\mathrm{a}} \mathrm{C}^{15}\right), 5.05(\mathrm{dd}, J=12.4,8.7 \mathrm{~Hz}, 1 \mathrm{H}$, $\mathrm{HC}^{3}$ ), 4.60 (d, $J=19.2 \mathrm{~Hz}, 1 \mathrm{H}, \mathrm{H}_{\mathrm{b}} \mathrm{C}^{15}$ ), 4.31 (ddd, $J=9.0,9.0$, $1.0 \mathrm{~Hz}, 1 \mathrm{H}, \mathrm{H}_{\mathrm{b}} \mathrm{C}^{5}$ ), 4.24 (ddd, $J=11.2,9.0,5.8 \mathrm{~Hz}, 1 \mathrm{H}, \mathrm{H}_{\mathrm{a}} \mathrm{C}^{5}$ ), 2.57 (dddd, $J=12.7,8.7,5.8,1.0 \mathrm{~Hz}, 1 \mathrm{H}, \mathrm{H}_{\mathrm{b}} \mathrm{C}^{4}$ ), 2.29 (dddd, $J=$ 12.5, 12.5, 11.2, 9.0 Hz, $\left.1 \mathrm{H}, \mathrm{H}_{\mathrm{a}} \mathrm{C}^{4}\right) .{ }^{13} \mathrm{C}\left\{{ }^{1} \mathrm{H}\right\}$ NMR $(126 \mathrm{MHz}$, MeCN- $d_{3}$ ): $\delta=194.7$ (C16), 174.4 (C2), 148.9 (C13), 135.5 (C17), 135.4 (C9), 134.9 (C20), 133.8 (C8), 133.21 (C10), 131.6 (C12), 129.8 (C19,21), 128.9 (C18,22), 125.1 (C11), 66.7 (C5), 58.6 (C3), 53.2 (C15), 28.4 (C4). ${ }^{15} \mathrm{~N}$ NMR (51 MHz, MeCN- $d_{3}$ ): $\delta=90.0$ (N6), 372.9 (N14). HRMS (ESI, pos.): $m / z$ calcd for $\mathrm{C}_{18} \mathrm{H}_{17} \mathrm{~N}_{2} \mathrm{O}_{7} \mathrm{~S}$ $[\mathrm{M}+\mathrm{H}]^{+} 405.0751$ found 405.0750. IR (DRIFT): $\bar{\nu}=3101,3953$, 2930, 2918, 1780, 1595, 1544, 1378, 1340, 1301, 1206, 1157, $1080,1063,760,742,700 \mathrm{~cm}^{-1} \cdot[\alpha]_{\mathrm{D}}^{25}=-21.0^{\circ}(c=0.00067 \mathrm{~g}$ $\mathrm{mL}^{-1}$ in $\left.\mathrm{MeCN}\right)$.

General procedure for cyclization to 1,4-oxazepanes $6 a-u$. The polymer-supported intermediate $\mathbf{3 a}-\mathbf{u}(500 \mathrm{mg})$ was cleaved in $\mathrm{TFA} / \mathrm{Et}_{3} \mathrm{SiH} / \mathrm{CH}_{2} \mathrm{Cl}_{2}(5 \mathrm{~mL}, 10: 1: 9)$ for $30 \mathrm{~min}$ (except for $3 \mathbf{n}$ and $3 \mathrm{~s}$ ) or $24 \mathrm{~h}$ (for derivatives $3 \mathrm{n}$ and $3 \mathrm{~s}$ ) at room temperature. Then the resin was washed three times with fresh cleavage cocktail $(5 \mathrm{~mL})$ and the combined fractions were evaporated using a stream of nitrogen and lyophilized overnight. The crude products were purified using RP-HPLC.

(-)-Ammonium $\quad(2 R, 5 S)$-2-phenyl-4-tosyl-1,4-oxazepane-5carboxylate $6 \mathrm{~g}$. Cleaved from $860 \mathrm{mg}$ of resin $3 \mathrm{~g}(0.273 \mathrm{mmol}$ $\mathrm{g}^{-1}, 0.235 \mathrm{mmol}$ of substrate). The separable mixture of C2 $R: S$ diastereomers in a ratio of $62: 38$, the isolation of major C2 $R$ epimer was performed. White amorphous solid $(16.1 \mathrm{mg}$, $0.043 \mathrm{mmol}, 18 \%)$. HPLC purity $97 \%$. NMR: mixture with $3 \%$ of C2 $S$ isomer. ${ }^{1} \mathrm{H}$ NMR $\left(500 \mathrm{MHz}, \mathrm{MeCN}-d_{3}\right): \delta=7.75(\mathrm{~d}, J=$ $8.3 \mathrm{~Hz}, 2 \mathrm{H}), 7.23-7.37$ (m, 7H), 4.81 (br. s, 5H, residual water), 4.55 (dd, $J=10.6,7.1 \mathrm{~Hz}, 1 \mathrm{H}), 4.32$ (d, $J=9.1 \mathrm{~Hz}, 1 \mathrm{H}), 4.02$ (ddd, $J=12.7,6.3,1.5 \mathrm{~Hz}, 1 \mathrm{H}), 3.78(\mathrm{ddd}, J=15.9,1.0,1.0 \mathrm{~Hz}, 1 \mathrm{H})$, $3.47-3.55$ (m, 1H), 3.49 (ddd, $J=12.7,9.5,1.2 \mathrm{~Hz}, 1 \mathrm{H}$ ), 2.47-2.54 (m, 1H), 2.39 (s, 3H), 2.13 (dddd, $J=15.9,10.6,9.1,1.6 \mathrm{~Hz}, 1 \mathrm{H})$. 
${ }^{13} \mathrm{C}\left\{{ }^{1} \mathrm{H}\right\}$ NMR $\left(126 \mathrm{MHz}, \mathrm{MeCN}-d_{3}\right): \delta=175.7,144.8,141.0$, 138.9, 130.7, 129.3, 128.7, 128.2, 127.0, 83.2, 67.7, 59.5, 54.4, 35.7, 21.5. HRMS (ESI, pos.): $m / z$ calcd for $\mathrm{C}_{19} \mathrm{H}_{25} \mathrm{~N}_{2} \mathrm{O}_{5} \mathrm{~S}[\mathrm{M}+\mathrm{H}]^{+}$ 393.1479 found 393.1482. IR (DRIFT): $\bar{\nu}=3062,3029,2950$, 2862, 11 917, 1723, 1596, 1450, 1334, 1306, 1171, 1152, 761, 746, $699 \mathrm{~cm}^{-1} \cdot[\alpha]_{\mathrm{D}}^{24}=-36.2^{\circ}\left(c=0.00062 \mathrm{~g} \mathrm{~mL}^{-1}, \mathrm{MeCN}\right)$.

$(-)-(S)-N$-(4-Methoxyphenethyl)-2-nitro- $N$-(2oxotetrahydrofuran-3-yl)benzenesulfonami-de 11n. Cleaved from $577 \mathrm{mg}$ of resin $3 \mathrm{n}\left(0.225 \mathrm{mmol} \mathrm{g}^{-1}, 0.130 \mathrm{mmol}\right.$ of substrate) for $24 \mathrm{~h}$ at room temperature. Pale yellow amorphous solid (17.8 mg, $0.042 \mathrm{mmol}$, 33\%). HPLC purity 99\%. ${ }^{1} \mathrm{H}$ NMR $\left(500 \mathrm{MHz}, \mathrm{MeCN}-d_{3}\right): \delta=8.13(\mathrm{dd}, J=7.7,1.5 \mathrm{~Hz}, 1 \mathrm{H}), 7.72-7.82$ $(\mathrm{m}, 3 \mathrm{H}), 7.11(\mathrm{~d}, J=8.5 \mathrm{~Hz}, 2 \mathrm{H}), 6.83(\mathrm{~d}, J=8.5 \mathrm{~Hz}, 2 \mathrm{H}), 4.90$ (dd, $J=11.7,9.0 \mathrm{~Hz}, 1 \mathrm{H}), 4.36-4.42(\mathrm{~m}, 1 \mathrm{H}), 4.25$ (ddd, $J=10.7$, 9.0, $6.3 \mathrm{~Hz}, 1 \mathrm{H}), 3.75(\mathrm{~s}, 3 \mathrm{H}), 3.45-3.54(\mathrm{~m}, 1 \mathrm{H}), 3.26-3.36(\mathrm{~m}$, $1 \mathrm{H}), 2.83-2.90(\mathrm{~m}, 2 \mathrm{H}), 2.48$ (dddd, $J=12.5,9.0,6.3,1.5 \mathrm{~Hz}, 1 \mathrm{H}$ ), 2.33-2.44 (m, 1H). ${ }^{13} \mathrm{C}\left\{{ }^{1} \mathrm{H}\right\} \mathrm{NMR}\left(126 \mathrm{MHz}, \mathrm{MeCN}-d_{3}\right): \delta=174.7$, $159.5,149.3$, 135.5, 133.3, 133.3, 131.4, 131.1, 130.9, 125.1, 114.9, 66.6, 58.5, 55.8, 49.9, 36.1, 27.9. HRMS (ESI, pos.): $\mathrm{m} / \mathrm{z}$ calcd for $\mathrm{C}_{19} \mathrm{H}_{21} \mathrm{~N}_{2} \mathrm{O}_{7} \mathrm{~S}[\mathrm{M}+\mathrm{H}]^{+} 421.1064$ found 421.1066. IR (DRIFT): $\bar{\nu}=2932,2836,1783,1542,1512,1367,1342,1250$, $1241,1159,785,752,708 \mathrm{~cm}^{-1} \cdot[\alpha]_{\mathrm{D}}^{24}=-76.9^{\circ}(c=0.00029 \mathrm{~g}$ $\left.\mathrm{mL}^{-1}, \mathrm{MeCN}\right)$.

General procedure for catalytical hydrogenation of nitro group $7 \mathbf{a}-\mathbf{f}, \mathbf{h}-\mathbf{m}, \mathbf{o}-\mathbf{r}, \mathbf{t}$, including $\mathbf{8 j}$, 9h, and 10r. The synthesis of anilines $\mathbf{7 a - f}, \mathbf{h}-\mathbf{m}, \mathbf{o}-\mathbf{r}, \mathbf{t}$ and amino-lactones $\mathbf{8 j}$, 9h was performed according to the reported protocol ${ }^{28}$ using $10 \% \mathrm{Pd} / \mathrm{C}$ or $\mathrm{PtO}_{2}$ (for derivatives 61, 6p, 6r, 6t, 5j) for $24 \mathrm{~h}$ at room temperature. The crude evaporators were purified by silica gel chromatography in $\mathrm{CH}_{2} \mathrm{Cl}_{2}$ /methanol $(\mathrm{MeOH})(9 / 1 ; \mathrm{v} / \mathrm{v}$, for derivatives $\mathbf{7 a - f}, \mathbf{h}-\mathbf{m}, \mathbf{o}-\mathbf{r}, \mathbf{t}$ ) or ethyl acetate (EA) $/ n$-hexane (Hex; $4 / 6$ or $1 / 1$; v/v; for derivatives $\mathbf{8 j}$, $9 \mathbf{h}$, respectively) to remove residual catalyst after hydrogenation, and then subjected to RPHPLC.

\section{$(-)-(2 R, 5 S)-4-((2-A m i n o p h e n y l) s u l f o n y l)-2-p h e n y l-1,4-$}

\section{oxazepa-ne-5-carboxylic acid $7 \mathbf{a}$}

Prepared from Wang resin. Cleaved from $785 \mathrm{mg}$ of resin 3a (0.140 mmol $\mathrm{g}^{-1}, 0.110 \mathrm{mmol}$ of substrate). The separable mixture of C2 $R: S$ diastereomers in a ratio of $56: 44$, the isolation of the major C2 $R$ epimer was performed. White amorphous solid (14.2 mg, $0.038 \mathrm{mmol}, 34 \%)$. HPLC purity 97\%. NMR: mixture with $2 \%$ of C2 $S$ isomer. ${ }^{1} \mathrm{H}$ NMR $(500 \mathrm{MHz}$, $\left.\mathrm{MeCN}-d_{3}\right): \delta=7.66\left(\mathrm{dd}, J=8.1,1.5 \mathrm{~Hz}, 1 \mathrm{H}, \mathrm{HC}^{19}\right), 7.34(\mathrm{ddd}, J=$ 8.3, 7.2, 1.5 Hz, $\left.1 \mathrm{H}, \mathrm{HC}^{17}\right), 7.23-7.30\left(\mathrm{~m}, 3 \mathrm{H}, \mathrm{HC}^{10-12}\right), 7.15(\mathrm{~m}$, $\left.2 \mathrm{H}, \mathrm{HC}^{9,13}\right), 6.84\left(\mathrm{dd}, J=8.3,1.0 \mathrm{~Hz}, 1 \mathrm{H}, \mathrm{HC}^{16}\right), 6.75$ (ddd, $J=$ 8.1, 7.2, $\left.1.0 \mathrm{~Hz}, 1 \mathrm{H}, \mathrm{HC}^{18}\right), 4.66\left(\mathrm{dd}, J=10.4,7.1 \mathrm{~Hz}, 1 \mathrm{H}, \mathrm{HC}^{5}\right)$, $4.16\left(\mathrm{~d}, J=9.5 \mathrm{~Hz}, 1 \mathrm{H}, \mathrm{HC}^{2}\right), 4.02(\mathrm{ddd}, J=12.7,6.3,1.1 \mathrm{~Hz}, 1 \mathrm{H}$, $\left.\mathrm{H}_{\mathrm{b}} \mathrm{C}^{7}\right), 3.70\left(\mathrm{~d}, J=16.1 \mathrm{~Hz}, 1 \mathrm{H}, \mathrm{H}_{\mathrm{a}} \mathrm{C}^{3}\right), 3.65(\mathrm{dd}, J=12.7,8.9 \mathrm{~Hz}$, $1 \mathrm{H}, \mathrm{H}_{\mathrm{a}} \mathrm{C}^{7}$ ), $3.50\left(\mathrm{dd}, J=16.1,9.5 \mathrm{~Hz}, 1 \mathrm{H}, \mathrm{H}_{\mathrm{b}} \mathrm{C}^{3}\right), 2.54$ (ddd, $J=$ 15.4, 7.1, 6.3 Hz, $1 \mathrm{H}, \mathrm{H}_{\mathrm{a}} \mathrm{C}^{6}$ ), 2.16 (dddd, $J=15.4,10.4,8.9$, $\left.1.1 \mathrm{~Hz}, 1 \mathrm{H}, \mathrm{H}_{\mathrm{b}} \mathrm{C}^{6}\right) .{ }^{13} \mathrm{C}\left\{{ }^{1} \mathrm{H}\right\} \mathrm{NMR}\left(126 \mathrm{MHz}, \mathrm{MeCN}-d_{3}\right): \delta=174.8$ (C21), 147.5 (C15), 141.0 (C8), 135.4 (C17), 131.0 (C19), 129.3 (C10,12), 128.7 (C11), 127.1 (C9,13), 121.9 (C14), 118.6 (C16), 117.7 (C18), 82.7 (C2), 67.5 (C7), 59.1 (C5), 54.1 (C3), 35.6 (C6). ${ }^{15} \mathrm{~N}$ NMR (51 MHz, MeCN- $d_{3}$ ): $\delta=99.9$ (N4), 63.0 (N20). HRMS (ESI, pos.): $m / z$ calcd for $\mathrm{C}_{18} \mathrm{H}_{21} \mathrm{~N}_{2} \mathrm{O}_{5} \mathrm{~S}[\mathrm{M}+\mathrm{H}]^{+} 377.1166$ found 377.1167. IR (DRIFT): $\bar{\nu}=2950,2864,1719,1617,1483,1452$,
$1317,1169,1140,751,698 \mathrm{~cm}^{-1} \cdot[\alpha]_{\mathrm{D}}^{24}=-64.1^{\circ}(c=0.00020 \mathrm{~g}$ $\left.\mathrm{mL}^{-1}, \mathrm{MeCN}\right)$.

Prepared from Wang-piperazine resin. Cleaved from $669 \mathrm{mg}$ of resin 3a $\left(0.601 \mathrm{mmol} \mathrm{g}^{-1}, 0.402 \mathrm{mmol}\right.$ of substrate). The separable mixture of $\mathrm{C} 2 R: S$ diastereomers in a ratio of $72: 28$, the isolation only of the major C2 $R$ epimer was performed. White amorphous solid (14.5 mg, $0.039 \mathrm{mmol}, 10 \%)$. HPLC purity 99\%. NMR: mixture with $2 \%$ of C2 $S$ isomer. The analytical data $\left({ }^{1} \mathrm{H}\right.$ and ${ }^{13} \mathrm{C}$ NMR, HRMS, IR (DRIFT) and $\left.[\alpha]_{\mathrm{D}}^{24}\right)$ corresponded with 7 a prepared from Wang resin.

(-)-(2R,5S)-4-((2-Aminophenyl)sulfonyl)-2-phenyl-1,4oxazepane-5-carboxamide $7 \mathbf{b}^{2 R}$. Cleaved from $1000 \mathrm{mg}$ of resin $3 \mathbf{b}\left(0.225 \mathrm{mmol} \mathrm{g}^{-1}, 0.225 \mathrm{mmol}\right.$ of substrate). The separable mixture of C2 $R: S$ diastereomers in a ratio of $45: 55$, the isolation of $\mathrm{C} 2 R$ epimer was performed. White amorphous solid (7.2 mg, $0.019 \mathrm{mmol}, 9 \%)$. HPLC purity 99\%. ${ }^{1} \mathrm{H}$ NMR (500 $\left.\mathrm{MHz}, \mathrm{MeCN}-d_{3}\right): \delta=7.70(\mathrm{dd}, J=8.2,1.5 \mathrm{~Hz}, 1 \mathrm{H}), 7.39(\mathrm{ddd}, J=$ 8.4, 7.1, 1.5 Hz, 1H), 7.26-7.33 (m, 3H), 7.20-7.21 (m, 2H), 6.89 (dd, $J=8.4,1.1 \mathrm{~Hz}, 1 \mathrm{H}), 6.80$ (ddd, $J=8.2,7.1,1.1 \mathrm{~Hz}, 1 \mathrm{H}), 6.34$ (br. s, 1H), 5.68 (br. s, 1H), 5.38 (br. s, 2H), 4.49 (ddd, $J=10.8$, $7.1,1.0 \mathrm{~Hz}, 1 \mathrm{H}), 4.28(\mathrm{dd}, J=9.3,1.2 \mathrm{~Hz}, 1 \mathrm{H}), 4.05$ (ddd, $J=12.9$, $6.3,1.5 \mathrm{~Hz}, 1 \mathrm{H}$ ), 3.82 (ddd, $J=16.2,1.2 \mathrm{~Hz}, 1.2,1 \mathrm{H}$ ), 3.67 (ddd, $J$ $=12.9,9.3,1.0 \mathrm{~Hz}, 1 \mathrm{H}), 3.53(\mathrm{dd}, J=16.2,9.6 \mathrm{~Hz}, 1 \mathrm{H}), 2.46$ (dddd, $J=15.7,7.1,6.3,1.0 \mathrm{~Hz}, 1 \mathrm{H}$ ), 2.21 (dddd, $J=15.7,10.8$, 9.3, $1.5 \mathrm{~Hz}, 1 \mathrm{H}) .{ }^{13} \mathrm{C}\left\{{ }^{1} \mathrm{H}\right\} \mathrm{NMR}\left(126 \mathrm{MHz}, \mathrm{MeCN}-d_{3}\right): \delta=174.2$, $147.4,140.9$, 135.7, 131.1, 129.3, 128.7, 127.1, 121.7, 118.8, 118.1, 82.7, 67.4 , 59.3, 54.7, 35.6. HRMS (ESI, pos.): $\mathrm{m} / \mathrm{z}$ calcd for $\mathrm{C}_{18} \mathrm{H}_{22} \mathrm{~N}_{3} \mathrm{O}_{4} \mathrm{~S}[\mathrm{M}+\mathrm{H}]^{+} 376.1326$ found 376.1326. IR (DRIFT): $\bar{\nu}=$ 3447, 3352, 3205, 3062, 3030, 2952, 2864, 1675, 1616, 1483, $1452,1318,1301,1140,748,698 \mathrm{~cm}^{-1} \cdot[\alpha]_{\mathrm{D}}^{24}=-62.5^{\circ}(c=$ $\left.0.00024 \mathrm{~g} \mathrm{~mL}^{-1}, \mathrm{MeCN}\right)$.

(+)-(2S,5S)-4-((2-Aminophenyl)sulfonyl)-2-phenyl-1,4oxazepa-ne-5-carboxamide $7 \mathbf{b}^{2 S}$. Cleaved from $1000 \mathrm{mg}$ of resin $3 \mathbf{b}\left(0.225 \mathrm{mmol} \mathrm{g}^{-1}, 0.225 \mathrm{mmol}\right.$ of substrate). The separable mixture of C2 $R: S$ diastereomers in a ratio of $45: 55$, the isolation of C2 $S$ epimer was performed. White amorphous solid (3.2 mg, $0.009 \mathrm{mmol}, 4 \%)$. HPLC purity 99\%. ${ }^{1} \mathrm{H}$ NMR (500 $\left.\mathrm{MHz}, \mathrm{MeCN}-d_{3}\right): \delta=7.58\left(\mathrm{dd}, J=8.1,1.6 \mathrm{~Hz}, 1 \mathrm{H}, \mathrm{HC}^{19}\right), 7.35$ $\left(\mathrm{ddd}, J=8.5,7.2,1.6 \mathrm{~Hz}, 1 \mathrm{H}, \mathrm{HC}^{17}\right), 7.28-7.32\left(\mathrm{~m}, 2 \mathrm{H}, \mathrm{HC}^{10,12}\right)$, 7.24-7.28 (m, $\left.1 \mathrm{H}, \mathrm{HC}^{11}\right), 7.17-7.20\left(\mathrm{~m}, 2 \mathrm{H}, \mathrm{HC}^{9,13}\right), 6.85$ (dd, $J=$ 8.5, $1.1 \mathrm{~Hz}, 1 \mathrm{H}, \mathrm{HC}^{16}$ ), 6.75 (br. s, $1 \mathrm{H}, \mathrm{H}_{\mathrm{b}} \mathrm{N} 22$ ), 6.70 (ddd, $J=8.2$, 7.2, $1.1 \mathrm{~Hz}, 1 \mathrm{H}, \mathrm{HC}^{18}$ ), 5.99 (br. s, $1 \mathrm{H}, \mathrm{H}_{\mathrm{a}} \mathrm{N}^{22}$ ), 5.62 (br. s, $2 \mathrm{H}$, $\mathrm{HN}^{20}$ ), $4.64\left(\mathrm{dd}, J=8.7,1.6 \mathrm{~Hz}, 1 \mathrm{H}, \mathrm{HC}^{2}\right), 4.59(\mathrm{dd}, J=4.5$, $4.5 \mathrm{~Hz}, 1 \mathrm{H}, \mathrm{HC}^{5}$ ), $3.94\left(\mathrm{ddd}, J=12.8,4.5,3.0 \mathrm{~Hz}, 1 \mathrm{H}, \mathrm{H}_{\mathrm{b}} \mathrm{C}^{7}\right.$ ), 3.78 $\left(\mathrm{ddd}, J=12.8,11.0,1.6 \mathrm{~Hz}, 1 \mathrm{H}, \mathrm{H}_{\mathrm{a}} \mathrm{C}^{7}\right), 3.63(\mathrm{dd}, J=14.2,1.6 \mathrm{~Hz}$, $1 \mathrm{H}, \mathrm{H}_{\mathrm{a}} \mathrm{C}^{3}$ ), $3.43\left(\mathrm{dd}, J=14.2,8.7 \mathrm{~Hz}, 1 \mathrm{H}, \mathrm{H}_{\mathrm{b}} \mathrm{C}^{3}\right), 2.30$ (dddd, $J=$ 15.8, 4.5, 4.5, $1.6 \mathrm{~Hz}, 1 \mathrm{H}, \mathrm{H}_{\mathrm{a}} \mathrm{C}^{6}$ ), 2.10 (dddd, $J=15.8,11.0,4.5$, $3.0 \mathrm{~Hz}, 1 \mathrm{H}$, overlap with water, $\left.\mathrm{H}_{\mathrm{b}} \mathrm{C}^{6}\right) .{ }^{13} \mathrm{C}\left\{{ }^{1} \mathrm{H}\right\}$ NMR $(126 \mathrm{MHz}$, MeCN- $d_{3}$ ): $\delta=174.4$ (C21), 148.0 (C15), 141.9 (C8), 135.7 (C17), 131.3 (C19), 129.3 (C10,12), 128.6 (C11), 126.6 (C9,13), 119.1 (C14), 118.7 (C16), 117.5 (C18), 81.4 (C2), 67.0 (C7), 59.4 (C5), 56.8 (C3), 33.0 (C6). HRMS (ESI, pos.): $\mathrm{m} / \mathrm{z}$ calcd for $\mathrm{C}_{18} \mathrm{H}_{22} \mathrm{~N}_{3} \mathrm{O}_{4} \mathrm{~S}[\mathrm{M}+\mathrm{H}]^{+} 376.1326$ found 376.1325. IR (DRIFT): $\bar{\nu}=$ 3448, 3350, 3216, 3061, 3029, 2969, 2954, 2920, 1676, 1616, $1483,1452,1318,1303,1142,752,699 \mathrm{~cm}^{-1} \cdot[\alpha]_{\mathrm{D}}^{24}=+271.4^{\circ}(c=$ $\left.0.00007 \mathrm{~g} \mathrm{~mL}^{-1}, \mathrm{MeCN}\right)$. 
(-)-(2R,5S)-4-((2-Amino-4-methoxyphenyl)sulfonyl)-2phenyl-1,4-oxazepane-5-carboxylic acid 7e. Cleaved from $606 \mathrm{mg}$ of resin $3 \mathrm{e}\left(0.381 \mathrm{mmol} \mathrm{g}^{-1}, 0.230 \mathrm{mmol}\right.$ of substrate). The separable mixture of C2 $R: S$ diastereomers in a ratio of $69: 31$, the isolation of major $\mathrm{C} 2 R$ epimer was performed. White amorphous solid (20.1 mg, $0.050 \mathrm{mmol}, 21 \%$ ). HPLC purity 99\%. ${ }^{1} \mathrm{H}$ NMR $\left(500 \mathrm{MHz}, \mathrm{MeCN}-d_{3}\right): \delta=7.58(\mathrm{~d}, J=8.9 \mathrm{~Hz}, 1 \mathrm{H})$, 7.22-7.30 (m, 3H), 7.15-7.16 (m, 2H), 6.31-6.35 (m, 2H), 5.02 (br. s, $2 \mathrm{H}), 4.61$ (dd, $J=10.9,7.1 \mathrm{~Hz}, 1 \mathrm{H}), 4.20$ (d, $J=9.5 \mathrm{~Hz}, 1 \mathrm{H})$, 4.02 (ddd, $J=12.7,6.4,1.2 \mathrm{~Hz}, 1 \mathrm{H}), 3.76$ (s, 3H), 3.58-3.39 (m, 2H), 3.50 (dd, $J=16.1,9.5 \mathrm{~Hz}, 1 \mathrm{H}), 2.46-2.54(\mathrm{~m}, 1 \mathrm{H}), 2.16$ (dddd, $J=15.4,10.9,9.2,1.2 \mathrm{~Hz}, 1 \mathrm{H}) .{ }^{13} \mathrm{C}\left\{{ }^{1} \mathrm{H}\right\}$ NMR $(126 \mathrm{MHz}$, MeCN- $\left.d_{3}\right): \delta=175.8,165.5,149.5,141.1,133.1,129.3,128.6$, 127.0, 114.3, 105.4, 101.5, 82.7, 67.6, 59.5, 56.1, 54.1, 35.7. HRMS (ESI, pos.): $m / z$ calcd for $\mathrm{C}_{19} \mathrm{H}_{23} \mathrm{~N}_{2} \mathrm{O}_{6} \mathrm{~S}[\mathrm{M}+\mathrm{H}]^{+} 407.1271$ found 407.1269. IR (DRIFT): $\bar{\nu}=3469,3370,3228,3029,2939$, 2864, 1736, 1725, 1605, 1450, 1303, 1133, 752, 699, $689 \mathrm{~cm}^{-1}$. $[\alpha]_{\mathrm{D}}^{24}=-16.8^{\circ}\left(c=0.00030 \mathrm{~g} \mathrm{~mL}^{-1}, \mathrm{MeCN}\right)$.

(-)-(2RS,5S)-4-((2-Amino-4-chlorophenyl)sulfonyl)-2-phenyl1,4-oxazepane-5-carboxylic acid $7 \mathbf{f}^{2 R S}$. Cleaved from $658 \mathrm{mg}$ of resin 3f $\left(0.381 \mathrm{mmol} \mathrm{g}^{-1}, 0.251 \mathrm{mmol}\right.$ of substrate). The inseparable mixture of $\mathrm{C} 2 R: S$ diastereomers in a ratio of $70: 30$, the interpretation of major $\mathrm{C} 2 R$ epimer was performed. White amorphous solid (21.0 mg, $0.051 \mathrm{mmol}, 20 \%)$. HPLC purity $78 \%$. NMR: mixture with $22 \%$ of $\mathrm{C} 2 S$ isomer. ${ }^{1} \mathrm{H}$ NMR $\left(500 \mathrm{MHz}, \mathrm{MeCN}-d_{3}\right): \delta=7.71(\mathrm{~d}, J=8.5 \mathrm{~Hz}, 1 \mathrm{H}), 7.39(\mathrm{~s}, 1 \mathrm{H})$, 7.29-7.30 (m, 2H), 7.20-7.26 (m, 3H), $6.90(\mathrm{~d}, J=8.3 \mathrm{~Hz}, 1 \mathrm{H})$, 6.01 (br. s, 2H), 4.66 (dd, $J=10.3,7.2 \mathrm{~Hz}, 1 \mathrm{H}), 4.41$ (d, $J=9.6 \mathrm{~Hz}$, $1 \mathrm{H}), 4.06$ (ddd, $J=12.6,6.3,1.5 \mathrm{~Hz}, 1 \mathrm{H}), 3.71(\mathrm{ddd}, J=12.6,8.9$, $1.0 \mathrm{~Hz}, 1 \mathrm{H}), 3.65$ (d, $J=16.0 \mathrm{~Hz}, 1 \mathrm{H}), 3.46(\mathrm{dd}, J=16.0,9.6 \mathrm{~Hz}$, 1H), 2.51-2.60 (m, 1H), 2.19 (dddd, $J=15.6,10.5,8.9,1.5 \mathrm{~Hz}$, 1H). ${ }^{13} \mathrm{C}\left\{{ }^{1} \mathrm{H}\right\} \operatorname{NMR}\left(126 \mathrm{MHz}, \mathrm{MeCN}-d_{3}\right): \delta=175.7,151.0,148.6$, 141.0, 132.6, 129.3, 128.7, 127.0, 121.4, 119.8, 114.7, 82.9, 67.6, 59.4, 54.5, 35.7. HRMS (ESI, pos.): $m / z$ calcd for $\mathrm{C}_{18} \mathrm{H}_{20} \mathrm{ClN}_{2} \mathrm{O}_{5} \mathrm{~S}$ $[\mathrm{M}+\mathrm{H}]^{+}$411.0776 found 411.0777. IR (DRIFT): $\bar{\nu}=3303,3064$, 3029, 2970, 2950, 2868, 1736, 1727, 1587, 1450, 1317, 1292, 1163, 758, $699 \mathrm{~cm}^{-1} \cdot[\alpha]_{\mathrm{D}}^{24}=-17.3^{\circ}\left(c=0.00098 \mathrm{~g} \mathrm{~mL}^{-1}\right.$, $\mathrm{MeCN})$.

(-)-(2R,5S)-4-((2-Aminophenyl)sulfonyl)-2-(2-fluorophenyl)1,4-oxazepane-5-carboxylic acid $7 \mathbf{i}^{2 R}$. Cleaved from $386 \mathrm{mg}$ of resin $3 \mathbf{i}\left(0.273 \mathrm{mmol} \mathrm{g}^{-1}, 0.105 \mathrm{mmol}\right.$ of substrate). The separable mixture of C2 $R: S$ diastereomers in a ratio of $29: 71$, the isolation of major C2 $R$ epimer was performed. White amorphous solid (1.6 mg, $0.004 \mathrm{mmol}, 4 \%$ ). HPLC purity $94 \% .{ }^{1} \mathrm{H}$ NMR (500 MHz, MeCN- $\left.d_{3}\right): \delta=7.64(\mathrm{dd}, J=8.2,1.5 \mathrm{~Hz}, 1 \mathrm{H})$, $7.28-7.37$ (m, 3H), 7.14 (ddd, $J=8.6,7.5,1.1 \mathrm{~Hz}, 1 \mathrm{H}$ ), 7.06 (ddd, $J=10.6,8.3,1.1 \mathrm{~Hz}, 1 \mathrm{H}), 6.82(\mathrm{dd}, J=8.2,1.1 \mathrm{~Hz}, 1 \mathrm{H}), 6.72(\mathrm{ddd}$, $J=8.2,7.2,1.1 \mathrm{~Hz}, 1 \mathrm{H}), 4.69(\mathrm{dd}, J=10.1,7.2 \mathrm{~Hz}, 1 \mathrm{H}), 4.64(\mathrm{dd}, J$ $=9.7,0.9 \mathrm{~Hz}, 1 \mathrm{H}), 4.03(\mathrm{ddd}, J=12.7,6.4,1.9 \mathrm{~Hz}, 1 \mathrm{H}), 3.85$ (ddd, $J=15.8,0.9,0.9 \mathrm{~Hz}, 1 \mathrm{H}), 3.68(\mathrm{ddd}, J=12.7,8.9,1.4 \mathrm{~Hz}$, $1 \mathrm{H}$ ), 3.55 (ddd, $J=15.8,9.7 \mathrm{~Hz}, 1 \mathrm{H}$ ), 2.54 (dddd, $J=15.6,7.2$, 6.4, $1.4 \mathrm{~Hz}, 1 \mathrm{H}$, overlap with water), 2.19 (dddd, $J=15.6,10.1$, 8.9, $1.9 \mathrm{~Hz}, 1 \mathrm{H}) .{ }^{13} \mathrm{C}\left\{{ }^{1} \mathrm{H}\right\} \mathrm{NMR}\left(126 \mathrm{MHz}, \mathrm{MeCN}-d_{3}\right): \delta=175.5$, $160.4(\mathrm{~d}, J=243.2 \mathrm{~Hz}), 147.4,135.3,130.9,130.6$ (d, $J=9.1 \mathrm{~Hz})$, 129.2, 129.2, 127.7 (d, $J=13.1 \mathrm{~Hz}), 125.3$ (d, $J=3.0 \mathrm{~Hz}), 121.8$, $117.7,116.8(\mathrm{~d}, J=26.2 \mathrm{~Hz}), 76.9,67.4,58.4,52.6$, 35.4. HRMS
(ESI, pos.): $m / z$ calcd for $\mathrm{C}_{18} \mathrm{H}_{20} \mathrm{FN}_{2} \mathrm{O}_{5} \mathrm{~S}[\mathrm{M}+\mathrm{H}]^{+} 395.1071$ found 395.1072. IR (DRIFT): $\bar{\nu}=3462$, 3372, 3214, 2926, 2867, 1724, $1617,1567,1483,1453,1317,1142,753 \mathrm{~cm}^{-1} \cdot[\alpha]_{\mathrm{D}}^{24}=-68.2^{\circ}(c$ $\left.=0.00011 \mathrm{~g} \mathrm{~mL}^{-1}, \mathrm{MeCN}\right)$.

(-)-(2S,5S)-4-((2-Aminophenyl)sulfonyl)-2-(2-fluorophenyl)1,4-oxazepane-5-carboxylic acid $7 \mathbf{i}^{2 S}$. Cleaved from $386 \mathrm{mg}$ of resin $3 \mathbf{i}\left(0.273 \mathrm{mmol} \mathrm{g}^{-1}, 0.105 \mathrm{mmol}\right.$ of substrate). The separable mixture of C2 $R: S$ diastereomers in a ratio of $29: 71$, the isolation of $\mathrm{C} 2 R$ epimer was performed. White amorphous solid (4.1 mg, $0.010 \mathrm{mmol}, 10 \%)$. HPLC purity 93\%. NMR: mixture with $7 \%$ of $\mathrm{C} 2 R$ isomer. ${ }^{1} \mathrm{H}$ NMR $\left(500 \mathrm{MHz}, \mathrm{MeCN}-d_{3}\right)$ : $\delta=7.57(\mathrm{dd}, J=8.0,1.5 \mathrm{~Hz}, 1 \mathrm{H}), 7.40(\mathrm{ddd}, J=7.5,7.5,1.7 \mathrm{~Hz}$, 1H), 7.26-7.31 (m, 2H), 7.14 (ddd, $J=8.6,7.5,1.1 \mathrm{~Hz}, 1 \mathrm{H}), 7.02$ (ddd, $J=10.6,8.2,1.1 \mathrm{~Hz}, 1 \mathrm{H}), 6.79(\mathrm{dd}, J=8.2,1.1 \mathrm{~Hz}, 1 \mathrm{H}), 6.65$ (ddd, $J=8.2,7.2,1.1 \mathrm{~Hz}, 1 \mathrm{H}), 4.93(\mathrm{dd}, J=8.9,2.0 \mathrm{~Hz}, 1 \mathrm{H}), 4.78$ (dd, $J=4.8,4.8 \mathrm{~Hz}, 1 \mathrm{H}), 4.02(\mathrm{ddd}, J=13.0,3.8,3.8 \mathrm{~Hz}, 1 \mathrm{H}), 3.78$ (ddd, $J=13.0,11.2,2.0 \mathrm{~Hz}, 1 \mathrm{H}), 3.61$ (dd, $J=13.8,2.0 \mathrm{~Hz}, 1 \mathrm{H}$ ), 3.43 (dd, $J=13.8,8.9 \mathrm{~Hz}, 1 \mathrm{H}$ ), 2.37 (dddd, $J=15.6,4.8,3.8$, $2.0 \mathrm{~Hz}, 1 \mathrm{H}), 2.24$ (dddd, $J=15.6,11.2,4.8,3.8 \mathrm{~Hz}, 1 \mathrm{H}) .{ }^{13} \mathrm{C}\left\{{ }^{1} \mathrm{H}\right\}$ NMR (126 MHz, MeCN- $d_{3}$ ): $\delta=174.3,159.9$ (d, $J=244.2 \mathrm{~Hz}$ ), 148.0, 135.3, 131.1, 130.5 (d, $J=8.1 \mathrm{~Hz}), 128.8,128.7,128.6$ (d, $J$ $=4.0 \mathrm{~Hz}), 125.4(\mathrm{~d}, J=3.0 \mathrm{~Hz}), 119.7,117.1,116.0(\mathrm{~d}, J=21.2$ $\mathrm{Hz}$ ), 76.0, 68.0, 59.9, 54.7, 33.8. HRMS (ESI, pos.): $\mathrm{m} / \mathrm{z}$ calcd for $\mathrm{C}_{18} \mathrm{H}_{20} \mathrm{FN}_{2} \mathrm{O}_{5} \mathrm{~S}[\mathrm{M}+\mathrm{H}]^{+} 395.1071$ found 395.1072. IR (DRIFT): $\bar{\nu}$ $=3463$, 3370, 2920, 2863, 1719, 1618, 1566, 1484, 1453, 1318, $1141,753 \mathrm{~cm}^{-1} \cdot[\alpha]_{\mathrm{D}}^{24}=-93.0^{\circ}\left(c=0.00050 \mathrm{~g} \mathrm{~mL}^{-1}, \mathrm{MeCN}\right)$.

(-)-(2R,5S)-4-((2-Aminophenyl)sulfonyl)-2-(3-fluorophenyl)1,4-oxazepane-5-carboxylic acid 7k. Cleaved from $600 \mathrm{mg}$ of resin $3 \mathbf{k}\left(0.353 \mathrm{mmol} \mathrm{g}^{-1}, 0.212 \mathrm{mmol}\right.$ of substrate). The separable mixture of C2 $R: S$ diastereomers in a ratio of $64: 36$, the isolation of major C2 $R$ epimer was performed. White amorphous solid (8.5 mg, $0.022 \mathrm{mmol}, 10 \%$ ). HPLC purity $99 \% .{ }^{1} \mathrm{H}$ NMR (500 MHz, MeCN- $\left.d_{3}\right): \delta=7.68(\mathrm{dd}, J=8.1,1.5 \mathrm{~Hz}, 1 \mathrm{H})$, 7.34 (ddd, $J=8.4,7.1,1.5 \mathrm{~Hz}, 1 \mathrm{H}), 7.29$ (ddd, $J=7.9,7.9,6.0 \mathrm{~Hz}$, $1 \mathrm{H}), 6.87-6.99$ (m, 3H), 6.85 (dd, $J=8.3,1.0 \mathrm{~Hz}, 1 \mathrm{H}), 6.75$ (ddd, $=8.1,7.1,1.0 \mathrm{~Hz}, 1 \mathrm{H}), 4.62(\mathrm{dd}, J=10.8,7.2 \mathrm{~Hz}, 1 \mathrm{H}), 4.19(\mathrm{~d}, J=$ $9.2 \mathrm{~Hz}, 1 \mathrm{H}), 4.02$ (ddd, $J=12.6,6.3,1.1 \mathrm{~Hz}, 1 \mathrm{H}), 3.70$ (ddd, $J=$ 15.8, 1.1, $1.1 \mathrm{~Hz}, 1 \mathrm{H}$ ), 3.65 (ddd, $J=12.6,9.2,0.7 \mathrm{~Hz}, 1 \mathrm{H}$ ), 3.50 (dd, $J=16.2,9.6 \mathrm{~Hz}, 1 \mathrm{H}), 2.45-2.56$ (m, 1H), 2.15 (dddd, $J=$ 15.8, 10.8, 9.2, $1.2 \mathrm{~Hz}, 1 \mathrm{H}) .{ }^{13} \mathrm{C}\left\{{ }^{1} \mathrm{H}\right\} \mathrm{NMR}\left(126 \mathrm{MHz}, \mathrm{MeCN}-d_{3}\right)$ : $\delta=175.4,163.6(\mathrm{~d}, J=243.2 \mathrm{~Hz}), 147.5,143.7(\mathrm{~d}, J=7.1 \mathrm{~Hz})$, 135.4, 131.1 (d, $J=9.1 \mathrm{~Hz}), 131.0,123.0$ (d, $J=2.0 \mathrm{~Hz}), 121.8$, 118.6, 117.6, 115.3 (d, $J=21.2 \mathrm{~Hz}), 113.8(\mathrm{~d}, J=23.2 \mathrm{~Hz}), 82.0$, 67.6, 59.4, 54.0, 36.0. HRMS (ESI, pos.): $\mathrm{m} / \mathrm{z}$ calcd for $\mathrm{C}_{18} \mathrm{H}_{20} \mathrm{FN}_{2} \mathrm{O}_{5} \mathrm{~S}[\mathrm{M}+\mathrm{H}]^{+} 395.1071$ found 395.1073. IR (DRIFT): $\bar{\nu}$ $=3469$, 3371, 2932, 2867, 1719, 1616, 1566, 1482, 1450, 1318, $1137,89,785,748,688 \mathrm{~cm}^{-1} \cdot[\alpha]_{\mathrm{D}}^{24}=-25.7^{\circ}(c=0.00070 \mathrm{~g}$ $\left.\mathrm{mL}^{-1}, \mathrm{MeCN}\right)$.

$(+)-(2 R, 5 S)-4-((2-A m i n o p h e n y l) s u l f o n y l)-2-(p$-tolyl)-1,4-oxazepane-5-carboxylic acid $7 \mathbf{m}$. Cleaved from $615 \mathrm{mg}$ of resin $3 \mathrm{~m}$ (0.173 $\mathrm{mmol} \mathrm{g}^{-1}, 0.168 \mathrm{mmol}$ of substrate). The separable mixture of $\mathrm{C} 2 R: S$ diastereomers in a ratio of $77: 23$, the isolation of major C2 $R$ epimer was performed. White amorphous solid (8.0 mg, $0.021 \mathrm{mmol}, 19 \%$ ). HPLC purity $99 \% .{ }^{1} \mathrm{H}$ NMR (500 MHz, MeCN- $\left.d_{3}\right): \delta=7.66(\mathrm{dd}, J=8.1,1.5 \mathrm{~Hz}, 1 \mathrm{H})$, 7.34 (ddd, $J=8.4,7.1,1.5 \mathrm{~Hz}, 1 \mathrm{H}), 7.11$ (d, $J=7.9 \mathrm{~Hz}, 2 \mathrm{H}), 7.04$ $(\mathrm{d}, J=7.9 \mathrm{~Hz}, 2 \mathrm{H}), 6.85(\mathrm{dd}, J=8.2,1.0 \mathrm{~Hz}, 1 \mathrm{H}), 6.75$ (ddd, $J=$ 
8.1, 7.1, $1.0 \mathrm{~Hz}, 1 \mathrm{H}), 4.67(\mathrm{dd}, J=10.8,7.1 \mathrm{~Hz}, 1 \mathrm{H}), 4.14(\mathrm{~d}, J=$ $9.0 \mathrm{~Hz}, 1 \mathrm{H}$ ), 4.01 (ddd, $J=12.7,6.3,1.5 \mathrm{~Hz}, 1 \mathrm{H}), 3.69$ (ddd, $J=$ 16.2, 1.0, $1.0 \mathrm{~Hz}, 1 \mathrm{H}$ ), 3.64 (ddd, $J=12.7,9.0,1.0 \mathrm{~Hz}, 1 \mathrm{H}), 3.49$ (dd, $J=16.2,9.6 \mathrm{~Hz}, 1 \mathrm{H}), 2.46-2.56(\mathrm{~m}, 1 \mathrm{H}), 2.29$ (s, 3H), 2.16 (dddd, $J=15.6,10.8,9.0,1.5 \mathrm{~Hz}, 1 \mathrm{H}) .{ }^{13} \mathrm{C}\left\{{ }^{1} \mathrm{H}\right\}$ NMR $(126 \mathrm{MHz}$, $\left.\mathrm{MeCN}-d_{3}\right): \delta=174.6,147.5,138.4,138.1,135.4,131.0,129.9$, 127.0, 122.0, 118.6, 117.6, 82.6, 67.4, 59.1, 54.1, 35.6, 21.1. HRMS (ESI, pos.): $m / z$ calcd for $\mathrm{C}_{19} \mathrm{H}_{23} \mathrm{~N}_{2} \mathrm{O}_{5} \mathrm{~S}[\mathrm{M}+\mathrm{H}]^{+} 391.1322$ found 391.1324. IR (DRIFT): $\bar{\nu}=3460,3368,3211,2950,2865$, 1719, 1617, 1599, 1483, 1452, 1317, 1169, 814, 748, $690 \mathrm{~cm}^{-1}$. $[\alpha]_{\mathrm{D}}^{24}=+34.8^{\circ}\left(c=0.00023 \mathrm{~g} \mathrm{~mL}^{-1}, \mathrm{MeCN}\right)$.

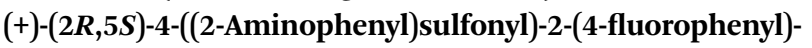
1,4-oxazepane-5-carboxylic acid 7o. Cleaved from $618 \mathrm{mg}$ of resin $30\left(0.261 \mathrm{mmol} \mathrm{g}^{-1}, 0.161 \mathrm{mmol}\right.$ of substrate). The separable mixture of C2 $R: S$ diastereomers in a ratio of $67: 33$, the isolation of major $\mathrm{C} 2 R$ epimer was performed. Pale yellow amorphous solid (6.3 mg, $0.016 \mathrm{mmol}, 10 \%$ ). HPLC purity $99 \%$. NMR: mixture with $6 \%$ of $\mathrm{C} 2 S$ isomer ${ }^{1} \mathrm{H}$ NMR $(500 \mathrm{MHz}$, MeCN- $\left.d_{3}\right): \delta=7.66(\mathrm{dd}, J=8.1,1.6 \mathrm{~Hz}, 1 \mathrm{H}), 7.33(\mathrm{ddd}, J=8.4$, $7.2,1.6 \mathrm{~Hz}, 1 \mathrm{H}$ ), 7.14 (br. d, $J=8.6 \mathrm{~Hz}, 2 \mathrm{H}$ ), 6.99 (br. d, $J=$ $8.9 \mathrm{~Hz}, 2 \mathrm{H}), 6.84(\mathrm{dd}, J=8.2,1.0 \mathrm{~Hz}, 1 \mathrm{H}), 6.74(\mathrm{ddd}, J=8.1,7.1$, $1.0 \mathrm{~Hz}, 1 \mathrm{H}), 4.58$ (dd, $J=10.8,7.0 \mathrm{~Hz}, 1 \mathrm{H}), 4.15$ (d, $J=9.3 \mathrm{~Hz}$, $1 \mathrm{H}), 3.99$ (ddd, $J=12.6,6.3,1.3 \mathrm{~Hz}, 1 \mathrm{H}), 3.60-3.67$ (m, 2H), 3.50 (dd, $J=16.2,9.6 \mathrm{~Hz}, 1 \mathrm{H}), 2.44-2.55(\mathrm{~m}, 1 \mathrm{H}), 2.14$ (dddd, $J=$ 15.6, 10.8, 9.2, 1.3 Hz, 1H). ${ }^{13} \mathrm{C}\left\{{ }^{1} \mathrm{H}\right\}$ NMR (126 MHz, MeCN- $\left.d_{3}\right)$ : $\delta=176.2,163.0(\mathrm{~d}, J=244.2 \mathrm{~Hz}), 147.5,137.2(\mathrm{~d}, J=3.0 \mathrm{~Hz})$, 135.4, 131.0, 129.0 (d, $J=9.1 \mathrm{~Hz}), 121.9,118.6,117.5,115.9$ (d, $J$ $=21.2 \mathrm{~Hz}$ ), 81.9, 67.7, 59.9, 54.0, 35.7. HRMS (ESI, pos.): $\mathrm{m} / \mathrm{z}$ calcd for $\mathrm{C}_{18} \mathrm{H}_{20} \mathrm{FN}_{2} \mathrm{O}_{5} \mathrm{~S}[\mathrm{M}+\mathrm{H}]^{+} 395.1071$ found 395.1073. IR (DRIFT): $\bar{\nu}=3460,3368,3210,2929,2863$, 1717, 1601, 1566, 1509, 1483, 1453, 1317, 1300, 1140, 834, 802, 748, $689 \mathrm{~cm}^{-1}$. $[\alpha]_{\mathrm{D}}^{24}=+35.3^{\circ}\left(c=0.00017 \mathrm{~g} \mathrm{~mL}^{-1}, \mathrm{MeCN}\right)$.

$(-)-(2 R, 5 S)-4-((2-A m i n o p h e n y l) s u l f o n y l)-2-(4-$

(trifluoromethyl)phenyl)-1,4-oxazepane-5-car-boxylic acid $7 q$. Cleaved from $510 \mathrm{mg}$ of resin $3 q\left(0.657 \mathrm{mmol} \mathrm{g}^{-1}, 0.335 \mathrm{mmol}\right.$ of substrate). The separable mixture of C2 $R: S$ diastereomers in a ratio of $61: 39$, the isolation of major $\mathrm{C} 2 R$ epimer was performed. Yellow amorphous solid (8.3 $\mathrm{mg}, 0.017 \mathrm{mmol}, 8 \%)$. HPLC purity $97 \%$. NMR: mixture with $4 \%$ of C2 $S$ isomer. ${ }^{1} \mathrm{H}$ NMR (500 MHz, MeCN- $\left.d_{3}\right): \delta=7.77(\mathrm{dd}, J=7.9,1.3 \mathrm{~Hz}, 1 \mathrm{H})$, 7.63 (br. d, $J=8.2 \mathrm{~Hz}, 2 \mathrm{H}), 7.50-7.58(\mathrm{~m}, 1 \mathrm{H}), 7.42$ (d, $J=8.2 \mathrm{~Hz}$, $1 \mathrm{H}$ ), 7.39 (br. d, $J=8.2 \mathrm{~Hz}, 2 \mathrm{H}$ ), 6.94-7.02 (m, 1H), 4.71 (dd, $J=$ 9.1, 7.2 Hz, 1H), 4.41 (d, $J=9.4 \mathrm{~Hz}, 1 \mathrm{H}), 4.08$ (ddd, $J=12.6,6.1$, $0.9 \mathrm{~Hz}, 1 \mathrm{H}), 3.76(\mathrm{dd}, J=16.2 \mathrm{~Hz}, 1 \mathrm{H}), 3.74(\mathrm{dd}, J=12.6,9.1 \mathrm{~Hz}$, $1 \mathrm{H}), 3.47$ (dd, $J=16.0,9.4 \mathrm{~Hz}, 1 \mathrm{H}), 2.51-2.63(\mathrm{~m}, 1 \mathrm{H}), 2.13-2.25$ $(\mathrm{m}, 1 \mathrm{H}) .{ }^{13} \mathrm{C}\left\{{ }^{1} \mathrm{H}\right\}$ NMR $\left(126 \mathrm{MHz}, \mathrm{MeCN}-d_{3}\right): \delta=174.3,149.9$, $145.2,135.6,130.7,130.1$ (q, $J=32.1 \mathrm{~Hz}), 127.7,126.2$ (q, $J=3.9$ $\mathrm{Hz}), 125.4$ (q, $J=272.0 \mathrm{~Hz}$ ), 123.2, 120.4, 115.3, 82.3, 67.5, 58.9, 54.1, 41.2, 35.5. HRMS (ESI, pos.): $m / z$ calcd for $\mathrm{C}_{19} \mathrm{H}_{20} \mathrm{~F}_{3} \mathrm{~N}_{2} \mathrm{O}_{5} \mathrm{~S}$ $[\mathrm{M}+\mathrm{H}]^{+} 445.1040$ found 445.1042. IR (DRIFT): $\bar{\nu}=3320,2937$, $2871,1731,1597,1459,1323,1164,1149,835,758 \mathrm{~cm}^{-1} \cdot[\alpha]_{\mathrm{D}}^{24}=$ $-73.1^{\circ}\left(c=0.00039 \mathrm{~g} \mathrm{~mL}^{-1}, \mathrm{MeCN}\right)$.

(-)-(2R,5S)-4-((2-Aminophenyl)sulfonyl)-2-(thiophen-3-yl)1,4-oxazepane-5-carboxylic acid $7 \mathrm{t}$. Cleaved from $570 \mathrm{mg}$ of resin $3 \mathrm{t}\left(0.213 \mathrm{mmol} \mathrm{g}^{-1}, 0.121 \mathrm{mmol}\right.$ of substrate). The separable mixture of $\mathrm{C} 2 R: S$ diastereomers in a ratio of $93: 7$, the isolation of major $\mathrm{C} 2 R$ epimer was performed. White amorphous solid (10.8 mg, $0.028 \mathrm{mmol}, 22 \%)$. HPLC purity 98\%. NMR: mixture with $2 \%$ of C2 $S$ isomer. ${ }^{1} \mathrm{H} \mathrm{NMR}(500 \mathrm{MHz}$, MeCN- $\left.d_{3}\right): \delta=7.76(\mathrm{dd}, J=7.8,0.9 \mathrm{~Hz}, 1 \mathrm{H}), 7.52(\mathrm{t}, J=7.8 \mathrm{~Hz}$, $1 \mathrm{H}), 7.39(\mathrm{~d}, J=8.3 \mathrm{~Hz}, 1 \mathrm{H}), 7.32(\mathrm{dd}, J=5.0,3.0 \mathrm{~Hz}, 1 \mathrm{H}), 7.15-$ $7.18(\mathrm{~m}, 1 \mathrm{H}), 6.94(\mathrm{dd}, J=5.0,1.3 \mathrm{~Hz}, 2 \mathrm{H}), 4.64(\mathrm{dd}, J=10.0$, $7.3 \mathrm{~Hz}, 1 \mathrm{H}$ ), 4.46 (d, $J=9.5 \mathrm{~Hz}, 1 \mathrm{H}$ ), 4.02 (ddd, $J=12.7,6.4$, $1.5 \mathrm{~Hz}, 1 \mathrm{H}), 3.74$ (d, $J=16.0 \mathrm{~Hz}, 1 \mathrm{H}), 3.69$ (ddd, $J=12.7,9.0$, $1.0 \mathrm{~Hz}, 1 \mathrm{H}), 3.49$ (dd, $J=16.0,9.5 \mathrm{~Hz}, 1 \mathrm{H}), 2.47-2.56(\mathrm{~m}, 1 \mathrm{H})$, 2.15 (dddd, $J=15.6,10.4,9.0,1.5 \mathrm{~Hz}, 1 \mathrm{H}) .{ }^{13} \mathrm{C}\left\{{ }^{1} \mathrm{H}\right\}$ NMR $(126$ $\left.\mathrm{MHz}, \mathrm{MeCN}-d_{3}\right): \delta=175.2,150.0,142.1,135.5,130.7,127.0$, 126.9, 123.0, 122.3, 120.2, 115.2, 79.3, 67.5, 59.3, 53.5, 35.7. HRMS (ESI, neg.): $m / z$ calcd for $\mathrm{C}_{16} \mathrm{H}_{17} \mathrm{~N}_{2} \mathrm{O}_{5} \mathrm{~S}_{2}[\mathrm{M}-\mathrm{H}]^{-}$ 381.0573 found 381.0581. IR (DRIFT): $\bar{\nu}=3297,3102,2950$, 2864, 1720, 1596, 1458, 1317, 1293, 1216, 1147, 1030, 955, $758 \mathrm{~cm}^{-1} \cdot[\alpha]_{\mathrm{D}}^{24}=-221.9^{\circ}\left(c=0.00029 \mathrm{~g} \mathrm{~mL}^{-1}, \mathrm{MeCN}\right)$.

$(-)-(S)-3-(1,1-D i o x o-4-(o-t o l y l) b e n z o[f][1,2,5]$ thiadiazepin2(5H)-yl)dihydrofuran-2(3H)-one $\mathbf{9 h}$. Cleaved from $592 \mathrm{mg}$ of resin $3 \mathbf{h}\left(0.521 \mathrm{mmol} \mathrm{g}^{-1}, 0.308 \mathrm{mmol}\right.$ of substrate). Pale yellow amorphous solid (21.6 mg, $0.058 \mathrm{mmol}, 19 \%)$. HPLC purity 99\%. ${ }^{1} \mathrm{H}$ NMR $\left(500 \mathrm{MHz}, \mathrm{MeCN}-d_{3}\right): \delta=7.77(\mathrm{dd}, J=8.0,1.6 \mathrm{~Hz}$, $1 \mathrm{H}), 7.40$ (ddd, $J=8.3,7.3,1.6 \mathrm{~Hz}, 1 \mathrm{H}), 7.34$ (ddd, $J=8.9,7.3$, $1.6 \mathrm{~Hz}, 1 \mathrm{H}), 7.26-7.31$ (m, 2H), 7.21-7.25 (m, 1H), 6.99 (dd, $J=$ 8.3, $0.9 \mathrm{~Hz}, 1 \mathrm{H}), 6.91-6.97$ (m, 2H), $4.94(\mathrm{~d}, J=1.2 \mathrm{~Hz}, 1 \mathrm{H}), 4.89$ $(\mathrm{dd}, J=11.3,8.8 \mathrm{~Hz}, 1 \mathrm{H}), 4.35(\mathrm{ddd}, J=9.0,9.0,1.6 \mathrm{~Hz}, 1 \mathrm{H}), 4.16$ (ddd, $J=10.8,9.0,6.1 \mathrm{~Hz}, 1 \mathrm{H}), 2.39-2.48(\mathrm{~m}, 1 \mathrm{H}), 2.38(\mathrm{~s}, 3 \mathrm{H})$, 2.05-2.12 (m, 1H). ${ }^{13} \mathrm{C}\left\{{ }^{1} \mathrm{H}\right\}$ NMR (126 MHz, MeCN- $\left.d_{3}\right): \delta=173.9$, $143.4,140.3$, 138.5, 136.6, 134.8, 131.3, 131.1, 130.5, 130.3, 128.3, 126.7, 120.9, 120.4, 101.4, 66.7, 58.6, 26.3, 19.5. HRMS (ESI, neg.): $m / z$ calcd for $\mathrm{C}_{19} \mathrm{H}_{17} \mathrm{~N}_{2} \mathrm{O}_{4} \mathrm{~S}[\mathrm{M}-\mathrm{H}]^{-} 369.0904$ found 369.0909. IR (DRIFT): $\bar{\nu}=3345,3066,3016,2920,1775,1663$, $1474,1335,1159,750 \mathrm{~cm}^{-1} \cdot[\alpha]_{\mathrm{D}}^{24}=-42.1^{\circ}\left(c=0.00063 \mathrm{~g} \mathrm{~mL}^{-1}\right.$, MeCN).

(+)-(S)-((2-Aminophenyl)sulfonyl)-t-homoserine 10r. Cleaved from $503 \mathrm{mg}$ of resin $3 \mathrm{r}\left(0.657 \mathrm{mmol} \mathrm{g}^{-1}, 0.330 \mathrm{mmol}\right.$ of substrate). Pale yellow amorphous solid (45.6 mg, $0.166 \mathrm{mmol}$, $50 \%)$. HPLC purity 99\%. ${ }^{1} \mathrm{H}$ NMR $\left(500 \mathrm{MHz}, \mathrm{MeCN}-d_{3}\right): \delta=7.63$ (dd, $J=8.0,1.4 \mathrm{~Hz}, 1 \mathrm{H}$ ), 7.34 (ddd, $J=8.3,7.2,1.4 \mathrm{~Hz}, 1 \mathrm{H}), 6.85$ (dd, $J=8.23,1.1 \mathrm{~Hz}, 1 \mathrm{H}), 6.75$ (ddd, $J=8.0,7.21 .1 \mathrm{~Hz}, 1 \mathrm{H}), 6.09$ (br. s, 1H), 5.27 (br. s, 2H), 4.23-4.30 (m, 1H), 4.05-4.14 (m, 2H), 2.27 (dddd, $J=12.5,8.6,5.9,1.2 \mathrm{~Hz}, 1 \mathrm{H}), 1.96-2.05(\mathrm{~m}, 1 \mathrm{H}) .{ }^{13} \mathrm{C}$ $\left\{{ }^{1} \mathrm{H}\right\}$ NMR $\left(126 \mathrm{MHz}, \mathrm{MeCN}-d_{3}\right): \delta=175.2,147.1,135.4,130.2$, 121.6, 118.3, 117.6, 66.6, 52.5, 30.7. HRMS (ESI, pos.): $\mathrm{m} / \mathrm{z}$ calcd for $\mathrm{C}_{10} \mathrm{H}_{13} \mathrm{~N}_{2} \mathrm{O}_{5} \mathrm{~S}[\mathrm{M}-\mathrm{H}]^{-} 273.0540$ found 273.0546. IR (DRIFT): $\bar{\nu}=3476,3375,3261,1770,1619,1482,1453,1318$, $754 \mathrm{~cm}^{-1} \cdot[\alpha]_{\mathrm{D}}^{24}=+5.8^{\circ}\left(c=0.00119 \mathrm{~g} \mathrm{~mL}^{-1}, \mathrm{MeCN}\right)$.

Cyclization to benzothiadiazepine 1,1-dioxide $9 \mathbf{j}$. The crude residue $8 \mathbf{j}$ was dissolved in $\mathrm{CH}_{2} \mathrm{Cl}_{2}(3.8 \mathrm{~mL})$ and TFA $(200 \mu \mathrm{L}$, $5 \%$ ) was added. The reaction mixture was shaken for $24 \mathrm{~h}$ at room temperature. Then it was evaporated to dryness using a stream of nitrogen. The product was purified by semipreparative RP-HPLC.

$(-)-(S)-3-(4-(2-B r o m o p h e n y l)-1,1-d i o x o b e n z o[f][1,2,5]$ thiadiazepin-2(5H)-yl)dihydrofuran-2(3H)-one $\mathbf{9 j}$. Cleaved from $589 \mathrm{mg}$ of resin $3 \mathbf{j}$ (0.521 $\mathrm{mmol} \mathrm{g}^{-1}, 0.307 \mathrm{mmol}$ of substrate). Pale yellow amorphous solid (16.8 mg, $0.039 \mathrm{mmol}, 13 \%)$. HPLC purity 98\%. ${ }^{1} \mathrm{H}$ NMR $\left(500 \mathrm{MHz}, \mathrm{MeCN}-d_{3}\right): \delta=7.78(\mathrm{dd}, J=8.0$, $1.6 \mathrm{~Hz}, 1 \mathrm{H}), 7.68$ (dd, $J=8.0,1.2 \mathrm{~Hz}, 1 \mathrm{H}), 7.48$ (dd, $J=7.6$, 
$1.9 \mathrm{~Hz}, 1 \mathrm{H}), 7.40-7.45$ (m, 2H), 7.35 (ddd, $J=8.0,7.4,1.9 \mathrm{~Hz}$, 1H), 7.02 (br. s, 1H), 7.00 (dd, $J=8.3,0.9 \mathrm{~Hz}, 1 \mathrm{H}), 6.97$ (ddd, $J=$ 8.0, 7.4, $0.9 \mathrm{~Hz}, 1 \mathrm{H}), 5.00$ (d, $J=1.2 \mathrm{~Hz}, 1 \mathrm{H}), 4.91$ (dd, $J=11.5$, $9.0 \mathrm{~Hz}, 1 \mathrm{H}$ ), 4.35 (ddd, $J=10.4,9.0,1.4 \mathrm{~Hz}, 1 \mathrm{H}), 4.15$ (ddd, $J=$ 10.9, 9.0, $6.1 \mathrm{~Hz}, 1 \mathrm{H}$ ), 2.47-2.58 (m, 1H), 2.06 (dddd, $J=12.4$, 8.8, 6.1, $1.4 \mathrm{~Hz}, 1 \mathrm{H}) .{ }^{13} \mathrm{C}\left\{{ }^{1} \mathrm{H}\right\}$ NMR $\left(126 \mathrm{MHz}, \mathrm{MeCN}-d_{3}\right): \delta=$ $173.7,142.4,140.2$, 137.5, 134.9, 134.0, 132.8, 132.1, 131.2, 128.7, 128.5, 124.1, 120.9, 120.8, 102.7, 66.7, 58.7, 26.2. HRMS (ESI, pos.): $m / z$ calcd for $\mathrm{C}_{18} \mathrm{H}_{16} \mathrm{BrN}_{2} \mathrm{O}_{4} \mathrm{~S}[\mathrm{M}+\mathrm{H}]^{+} 435.0009$ found 435.0011. IR (DRIFT): $\bar{\nu}=3349,2921,2851,1776,1662$, $1594,1475,1338,1162,751 \mathrm{~cm}^{-1} \cdot[\alpha]_{\mathrm{D}}^{24}=-51.7^{\circ}(c=0.00029 \mathrm{~g}$ $\left.\mathrm{mL}^{-1}, \mathrm{MeCN}\right)$.

\section{Conflicts of interest}

There are no conflicts to declare.

\section{Acknowledgements}

This work was supported by an internal grant from Palacký University (IGA_PrF_2020_012).

\section{Notes and references}

1 Y. Du, D. P. Garden, L. Wang, B. S. Zhorov and K. Dong, J. Biol. Chem., 2011, 286, 13151-13160.

2 K. Ishimoto, K. Yamaguchi, A. Nishimoto, M. Murabayashi and T. Ikemoto, Org. Process Res. Dev., 2017, 21, 2001-2011.

3 T. Yukawa, Y. Nakada, N. Sakauchi, T. Kamei, M. Yamada, Y. Ohba, I. Fujimori, H. Ueno, M. Takiguchi, M. Kuno, I. Kamo, H. Nakagawa, Y. Fujioka, T. Igari, Y. Ishichi and T. Tsukamoto, Bioorg. Med. Chem., 2016, 24, 3716-3726.

4 K. Audouze, E. Ø. Nielsen and D. Peters, J. Med. Chem., 2004, 47, 3089-3104.

5 M. H. Serrano-Wu, D. R. S. Laurent, Y. Chen, S. Huang, K.-R. Lam, J. A. Matson, C. E. Mazzucco, T. M. Stickle, T. P. Tully, H. S. Wong, D. M. Vyas and B. N. Balasubramanian, Bioorg. Med. Chem. Lett., 2002, 12, 2757-2760.

6 S. Kaneko, M. Arai, T. Uchida, T. Harasaki, T. Fukuoka and T. Konosu, Bioorg. Med. Chem. Lett., 2002, 12, 1705-1708.

7 G. Sharma, J. Y. Park and M. S. Park, Arch. Pharmacal Res, 2008, 31, 838.

8 S. Kaneko, M. Arai, T. Uchida, T. Harasaki, T. Fukuoka and

T. Konosu, Bioorg. Med. Chem. Lett., 2002, 12, 1705-1708.

9 Insmed Incorporated, USA, PCT Int. Appl., 2020, 82.

10 Insmed Incorporated, USA, PCT Int. Appl., 2020, 51.

11 AstraZeneca AB, Swed., PCT Int. Appl., 2019, 106.
12 Insmed Incorporated, USA and AstraZeneca AB, PCT Int. Appl., 2018, 61.

13 M. Bezanson, J. Pottel, R. Bilbeisi, S. Toumieux, M. Cueto and N. Moitessier, J. Org. Chem., 2013, 78, 872-885.

14 M. J. Deka, K. Indukuri, S. Sultana, M. Borah and A. K. Saikia, J. Org. Chem., 2015, 80, 4349-4359.

15 S. J. Gharpure, D. S. Vishwakarma and S. K. Nanda, Org. Lett., 2017, 19, 6534-6537.

16 J. K. Vandavasi, W.-P. Hu, H.-Y. Chen, G. C. Senadi, C.-Y. Chen and J.-J. Wang, Org. Lett., 2012, 14, 3134-3137.

17 S. J. Gharpure and J. V. K. Prasad, Eur. J. Org. Chem., 2013, 2013, 2076-2079.

18 J.-C. Castillo, J. Portilla, B. Insuasty, J. Quiroga and R. Abonia, Curr. Org. Chem., 2018, 15, 370-379.

19 S. K. Das, A. K. Srivastava and G. Panda, Tetrahedron Lett., 2010, 51, 1483-1485.

20 P. Ghosh, M. J. Deka and A. K. Saikia, Tetrahedron, 2016, 72, 690-698.

21 J. Nonnenmacher, F. Grellepois and C. Portella, Eur. J. Org. Chem., 2009, 2009, 3726-3731.

22 T. Bera, B. Singh, T. A. Hamlin, S. C. Sahoo and J. Saha, J. Org. Chem., 2019, 84, 15255-15266.

23 R. Zhou, J. Wang, C. Duan and Z. He, Org. Lett., 2012, 14, 6134-6137.

24 K. Samanta and G. Panda, Org. Biomol. Chem., 2011, 9, 73657371.

25 M. K. Jackl, L. Legnani, B. Morandi and J. W. Bode, Org. Lett., 2017, 19, 4696-4699.

26 P. Králová, V. Fülöpová, M. Maloň, T. Volná, I. Popa and M. Soural, ACS Comb. Sci., 2017, 19, 173-180.

27 P. Králová, M. Maloň, T. Volná, V. Ručilová and M. Soural, ACS Comb. Sci., 2017, 19, 670-674.

28 P. Králová, M. Maloň and M. Soural, ACS Comb. Sci., 2017, 19, 770-774.

29 V. Ručilová, P. Králová and M. Soural, Eur. J. Org. Chem., 2017, 2017, 7034-7039.

30 M. Ručilová, V. Maloň and M. Soural, Eur. J. Org. Chem., 2018, 2018, 564-570.

31 F. Filira, B. Biondi, L. Biondi, E. Giannini, M. Gobbo, L. Negri and R. Rocchi, Org. Biomol. Chem., 2003, 1, 30593063.

32 C. R. Zwick and H. Renata, Tetrahedron, 2018, 74, 6469-6473. 33 V. Fülöpová, A. Krchňáková, E. Schütznerová, J. Zajíček and V. Krchňák, J. Org. Chem., 2015, 80, 1795-1801.

34 V. Fülöpová, T. Gucký, M. Grepl and M. Soural, ACS Comb. Sci., 2012, 14, 651-656.

35 G. E. Martin and C. E. Hadden, J. Nat. Prod., 2000, 63, 543585. 